\title{
End-Cretaceous Quartz Arenite Formation in an Estuarian Environment under Brine Influence, N. Germany; Linked to both Deccan Volcanism and Chicxulub Impact Degassing during Climate Change
}

\author{
Werner Schneider ${ }^{1}$, Elias Salameh ${ }^{2}$ \\ ${ }^{1}$ Formerly, Braunschweig Technical University, Braunschweig, Germany \\ ${ }^{2}$ University of Jordan, Amman, Jordan \\ Email: salameli@ju.edu.jo
}

How to cite this paper: Schneider, W. and Salameh, E. (2020) End-Cretaceous Quartz Arenite Formation in an Estuarian Environment under Brine Influence, N. Germany; Linked to both Deccan Volcanism and Chicxulub Impact Degassing during Climate Change. Open Journal of Geology, 10, 1091-1118.

https://doi.org/10.4236/ojg.2020.1011053

Received: October 22, 2020

Accepted: November 27, 2020

Published: November 30, 2020

Copyright $\odot 2020$ by author(s) and Scientific Research Publishing Inc. This work is licensed under the Creative Commons Attribution-NonCommercial International License (CC BY-NC 4.0). http://creativecommons.org/licenses/by-nc/4.0/ (c) (i) \& Open Access

\begin{abstract}
Maastrichtian off-shore carbonate sediments and transitional estuarian quartz arenite (primarily subarkosic/arkosic) deposited in N Germany, underwent indirect effects by end-Cretaceous plume volcanism (Caribbean Arc/Antilles, Amirante Arc/Seychelles, Deccan Traps) and by the Chicxulub impact during climate change. In addition, brines of local salt structures had increasing influence on pore water chemistry of siliciclastics deposited in rim synclines and sub-rosion bowls during the transition from salt pillow state (Upper Campanian/Maastrichtian) to diapirism since the KPgB (66.043 Ma) until end-Paleocene. As main drivers degassing $\left(\mathrm{CO}_{2}, \mathrm{SO}_{2}\right.$ et al.), temperature rise, acid rain/metal toxicity of both volcanic and impact origin caused kill effects by acidification ( $\mathrm{pH}$-drop) of sea water resp. dissolution processes on land initiated by complex acid mixtures onto both marine and continental sediments; all in all, leaving a remarkable reduction of the clastics' primary mineral content, accompanied by kaolinite in-situ neoformation $(\rightarrow$ quartz, kaolinite). Furthermore, driving effects even controlled lithofacies and sequence-analytical patterns (LST, TST, HST). Around the Lower/Upper Maastrichtian B. (MFS) radiolarian ooze was deposited across flat estuarian mouth channels during an ingression (tsunami), originally as soft pebbles, then diagenetically slightly consolidated. Surprisingly, the radiolarian skeletons normally composed of opal or celestite, were identified as $\beta$-quartz and elementary silicon. The latter hitherto unknown in nature, demands extreme reducing conditions (in Industries: by elementary $\mathrm{A} 1, \mathrm{Mg}, \mathrm{C}$ ) in pore water as
\end{abstract}


possibly given by brines (see Atlantis II-Deep, Red Sea). The top portions of the uppermost Maastrichtian deposits of N Germany were eroded by the KPgB-convulsive events. However, recent publications (i.e. from Seymour Island, Antarctica) make evident that Deccan volcanism played obviously a prime role versus the Chicxulub impact during reversal magnetization (Chron $29 \mathrm{R}$ ). Thus, there exists a high probability that plume volcanism had important influence on the quartz arenite in-situ formation by degassing and related acid in combination with brines in trap position of the ascending salt diapirs. Accordingly, Price's concept (2001) major impacting may cause plate motion, has to be modified towards the version plume mechanism and may have the same or even stronger effect, thereby relating to recent studies on the Arabian Platform, Jordan. A synopsis of Phanerozoic loss of biodiversity-events caused by both plume volcanism and impacting comparatively exposes Homo sapiens since the Industrial Revolution as a geological force in biotic as well as abiotic processes in Earth History.

\section{Keywords}

Indirect Effects, Diagenesis

\section{Introduction}

"In Science new ideas aren't a priori right because they are new; just so former ones aren't wrong because they are past... Everywhere, where generally accepted ideas underlie uncritical use and proofs that don't coincide with them, are simply wiped off or not mentioned since they don't fit into the representation, science moves into oppression".

Thomas Gold, Geo-Universalist [1], transl. Sch.

Since half a century abundant publications have been written on "direct" effects caused by major impacting as shock metamorphism, impact cratering, fall out/back deposits, boundary clay, tektites, mass extinction etc., see synoptical papers i.e. [2] [3].

However, "indirectly" triggered effects via climate change as wildfire, whirlstorm, tsunami [2] [3] [4] [5], acid rain [6], cosmic winter [7] [8] as well as metal toxicity, and magma degassing have been less taken into account with special regard to dissolution processes in marine and continental environments as well [9] [10] [11] [12] [13].

In magma dissolved gases $\left(\mathrm{CO}_{2}, \mathrm{H}_{2} \mathrm{O}, \mathrm{H}_{2}\right.$, $\mathrm{HCI}, \mathrm{HF}, \mathrm{CI}_{2}, \mathrm{~F}_{2}, \mathrm{H}_{2} \mathrm{~S}, \mathrm{~S}_{2}, \mathrm{SO}_{2}, \mathrm{SO}_{3}$, and $\mathrm{N}_{2}$ ) provide aggressive mixtures of acids whose $\mathrm{pH}$ may fall below zero being incalculable ([13], Table 1 and Table 2). Furthermore, metal compounds (i.e. $\mathrm{FeCI}_{2}, \mathrm{MnCI}_{2}, \mathrm{PbCI}_{2}, \mathrm{AgCl}, \mathrm{SnCI}_{2}, \mathrm{MoO}_{3}, \mathrm{WO}_{3}$, and $\mathrm{H}_{2} \mathrm{O}$ ) are dissolved in magmatic gas under high pressure [13]. It should be stressed that the weight of volatiles moves in order of a few percent of the total fluid magma weight in the same eruption. 
Table 1. Analysis of fumarole gases from Kilauea, Hawai and Erta'Ale, Ethiopia, both basaltic sources (mol-\%, [13]).

\begin{tabular}{ccccccc}
\hline \multicolumn{5}{c}{ Kilauea } & & \multicolumn{3}{c}{ Erta'Ale } \\
\hline $\mathrm{H}_{2} \mathrm{O}$ & 36.18 & 61.56 & 67.52 & 84.8 & 69.9 & 79.4 \\
$\mathrm{CO}_{2}$ & 47.68 & 20.93 & 16.96 & 7.0 & 15.8 & 10.4 \\
$\mathrm{CO}$ & 1.46 & 0.59 & 0.58 & 0.27 & 0.68 & 0.46 \\
$\mathrm{COS}$ & & & & 0.001 & 0.01 & 0.009 \\
$\mathrm{SO}_{2}$ & 11.15 & 11.42 & 7.91 & 5.1 & 10.2 & 6.5 \\
$\mathrm{SO}_{3}$ & 0.42 & 0.55 & 2.46 & & & \\
$\mathrm{~S}_{2}$ & 0.04 & 0.25 & 0.09 & 0.4 & 0.0 & 0.5 \\
$\mathrm{HCl}$ & 0.08 & 0.00 & 0.20 & 1.28 & 1.22 & 0.42 \\
$\mathrm{H}_{2}$ & 0.48 & 0.32 & 0.96 & 0.85 & 2.11 & 1.49 \\
$\mathrm{~N}_{2}$ & 2.41 & 4.13 & 3.35 & 0.10 & 0.25 & 0.18 \\
$\mathrm{Ar}$ & 0.14 & 0.31 & 0.66 & 0.001 & 0.001 & 0.001 \\
\hline
\end{tabular}

Sources: Shepherd, 1938, p.321 (Kilauea); Giggenbach and Le Guern, 1976, p.26 (Erta'Ale). The three Kilauea samples are Shepherd's Nos. J8, J11, J13; the first two from Erta'Ale are representative individual samples, and the third is an average of 18 samples. Shepherd calculated all chlorine as $\mathrm{Cl}_{2}$; his numbers are expressed here as $\mathrm{HCl}$, for ease of comparison with the Erta'Ale analyses.

Table 2. Analysis of fumarol gases from Showa-Shinzan, Japan (Vol-\% totaled to $100 \%$ ) in connection with a dacite dome [13].

\begin{tabular}{|c|c|c|c|c|c|c|c|}
\hline \multirow{13}{*}{ 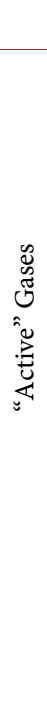 } & \multicolumn{7}{|c|}{ Temperature, ${ }^{\circ} \mathrm{C}$} \\
\hline & Gases & 750 & 700 & 645 & 464 & 328 & 194 \\
\hline & $\mathrm{CO}_{2}$ & 65.0 & 61.1 & 64.3 & 91.1 & 89.5 & 76.4 \\
\hline & $\mathrm{CH}_{4}$ & 0.08 & 0.14 & 0.14 & 0.14 & 0.15 & 0.16 \\
\hline & $\mathrm{NH}_{3}$ & 0.06 & 0.007 & 0.01 & 0.10 & 0.007 & 0.01 \\
\hline & $\mathrm{H}_{2}$ & 25.0 & 24.5 & 21.3 & 5.12 & 6.96 & 13.6 \\
\hline & $\mathrm{HCl}$ & 5.39 & 8.61 & 8.61 & 1.51 & 1.48 & 4.66 \\
\hline & $\mathrm{HF}$ & 2.76 & 3.54 & 3.51 & 0.88 & 0.65 & 0.43 \\
\hline & $\mathrm{H}_{2} \mathrm{~S}$ & 0.10 & 0.62 & 0.53 & 1.07 & 1.05 & 4.27 \\
\hline & $\mathrm{SO}_{2}$ & 1.66 & 1.50 & 1.60 & 0.12 & 0.14 & 0.50 \\
\hline & Total active gases & 0.723 & 0.592 & 0.569 & 0.859 & 0.948 & 0.258 \\
\hline & $\mathrm{N}_{2}$ & 0.026 & 0.019 & 0.021 & 0.042 & 0.052 & 0.026 \\
\hline & $\mathrm{H}_{2} \mathrm{O}$ & 99.25 & 99.39 & 99.41 & 99.10 & 99.00 & 99.72 \\
\hline
\end{tabular}

Source: White and Waring, 1963, P. 24.

Such acid mixtures cause the dissolution of toxic metals (AI, Be, $\mathrm{Pb}, \mathrm{Hg}, \mathrm{Cd}$, $\mathrm{Ti}, \mathrm{Cu}, \mathrm{Fe}, \mathrm{Ni}, \mathrm{Mn}, \mathrm{Sr}, \mathrm{U}, \mathrm{V}, \mathrm{Zn}$ ) substituted in soluble compounds of soils, sediments and rocks via acid rain [9].

As experiments verify, a mixture of $\mathrm{HNO}_{3}, \mathrm{H}_{2} \mathrm{SO}_{4}$ and $\mathrm{HF}$ may almost completely dissolve $\beta$-quartz in order to enrich high pressure $\mathrm{SiO}_{2}$-modifications (coesite, stishovite) from shocked silicate rocks [14].

Figure 1 shows the solubility of silica under normal conditions. 


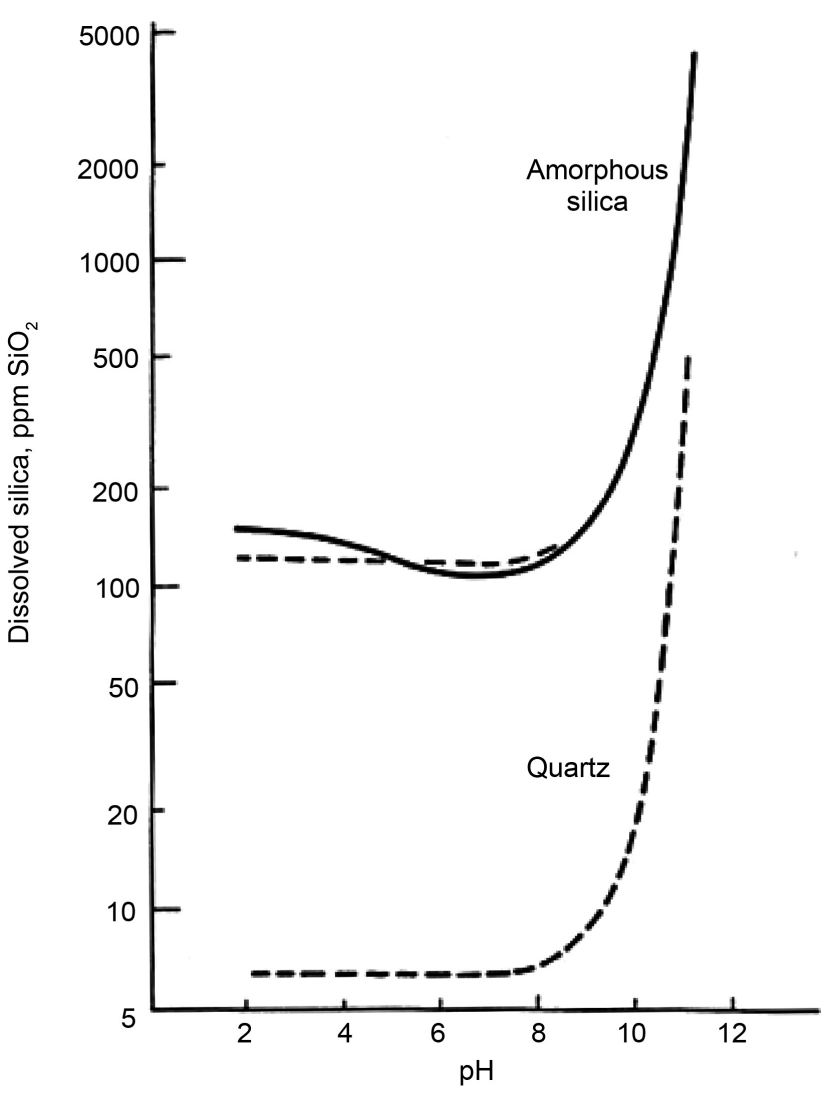

Figure 1. Solubility of silica at $25^{\circ} \mathrm{C}$. Upper dashed line calculated (120 ppm $\mathrm{SiO}_{2}$ at $\mathrm{pHs}$ below 8), lower dashed line calculated (6 ppm $\mathrm{SiO}_{2}$ in neutral and acid solutions), [13].

Figure 2 exposes dissolution and overgrowth patterns of the ultra-stable heavy minerals zircon (A), tourmaline (B), and of clastic quartz grains (C, D) as example for effects caused by rare events' degassing [15] [16].

Even sequence-analytical patterns like architectural elements (i.e. fining upward cycles, progradation, retrogradation) are obviously concerned [15] [16]. Thus, both volcanism (predominantly plum v.) and/or major impacting provide kill effects for global mass extinction as well as for physical/chemical consequences relating to terrestrial sediments during transport, deposition and diagenesis [17] [18] [19] [20].

So during sea water acidification via climate change, a temperature pulse by $\mathrm{CO}_{2}$-rise, $\mathrm{pH}$-dropping and metal toxicity directed the kill rate of benthic bivalves and ammonite sp. on Seymour Island, Antarctica, recovered by using a new clumped isotope analysis of high resolution from a hiatus-free section [19]. The results reveal two temperature pulses verifying the biotic turnover by both end-Cretaceous Deccan volcanism (main pulse) and the Chicxulub impact.

A recent paper [20] submits similar results by application of boron isotope analysis of planctic and benthic foraminifera showing kill mechanism for ecologic collapse in global marine realm by impact-induced ocean water acidification ( $\mathrm{pH}$-drop) as well as the recovery of marine carbon recycling after the 

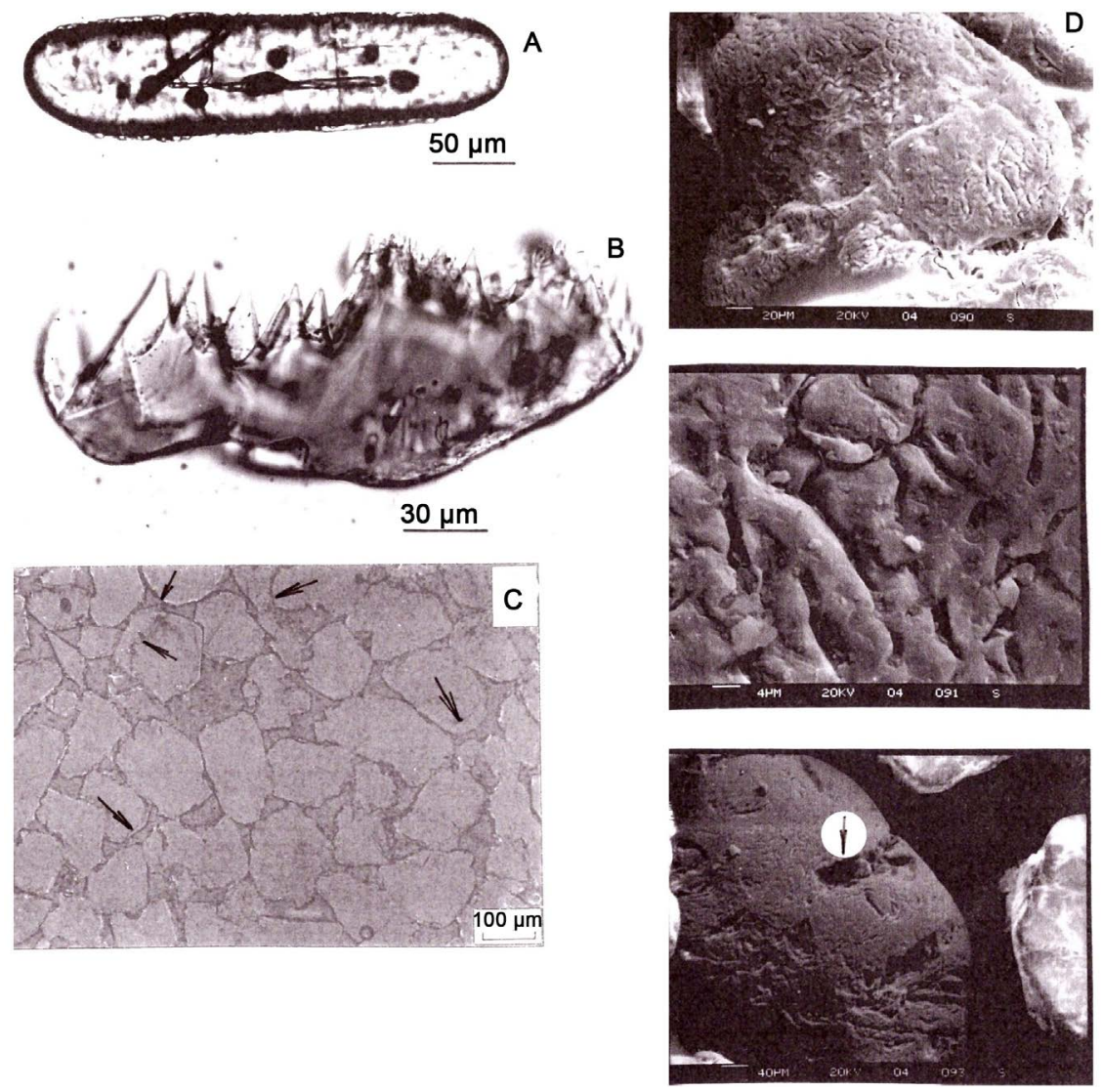

Figure 2. Dissolution patterns of detrital grains of quartz arenite [15] [16]. (A): Zircon showing "zig-zag sawfish" overgrowth, euhedral faces and subsequent traces of dissolution, inclusions of elongated smaller zircon crystals and opaque minerals: grain mounts micrograph, Disi F., Lower Ordovician, Jordan. (B): Tourmaline with excessive "hack saw termination"; grain mount micrograph, parallel polars, Um Ishrin F., Upper Cambrian, Jordan. (C): Lower Cretaceous (Kurnub F.) quartz arenite, porosity $25 \%-30 \%$. Thin section exposes subordinate syntaxial overgrowth of corroded angular quartz grains originally well rounded (arrow!). Wadi Zarqa Ma'in, Jordan. (D): Corroded surface (dissolution; micro channels) of quartz grains, additional impact casts (arrow). Scanning micrograph: Upper Maastrichtian "glass sand", Uhry pit (Evers), Subhercynian, North Germany [31 and additional report, unpubl.].

extinction time-span; however, without differentiating the intensity of kill effect by both volcanism and impact.

Entering the field of plate tectonics, Price [21] used the Atlas-System, Version 3.3 in order to recover the age of end-Cretaceous "rare events" (Caribbean Arc/Antilles, Amirante Arc/Seychelles, Deccan Trap Flood Basalt, Scotia Arc, Chicxulub Impact, Yucatan).

This method deals with the parameters of abrupt change of both direction and speed of plate motion in connection with plume activity. The analytical error bar may be higher (up to a few \%) than in the most recent chronostratigraphic table [20] [21].

The Atlas-System developed by A. Smith and coworkers, Cambridge University UK. represents a global mapping reconstruction system for P.C. in order to 
design maps and tracks of continents and individual islands through various Phanerozoic episodes. So it provides a mapmaking package comprising EULER-rotations and a variety of utilities for creating paleogeographic reconstructions of the last $600 \mathrm{Ma}$ and estimates of the past position of present-day shaped coastlines.

Hence, the clue of our paper tells: if such highly acidic mixtures generated by both volcanism and major impacting attack clastic sediments through a certain time-span in a suitable geologic setting of arkosic/subarkosic deposits (stable platforms, rim synclines as trap), mature quartz arenite may be the final product in paragenesis with neoformed kaolinite [15] [16].

Both relevant outcrops in North Germany are localized in the Sub-Hercynian, Northern Harz-foreland having been subject of "glass sand"-exploitation since 1925:

- Uhry, sheet Supplingen: latitude $57^{\circ} 97^{\prime} 500^{\prime \prime}$, longitude $44^{\circ} 22^{\prime} 600^{\prime \prime} / 160^{\prime \prime}$.

- Walbeck, sheet Helmstedt: latitude 57 $94^{\prime} 555^{\prime \prime}-57^{\circ} 95^{\prime} 995^{\prime \prime}$, longitude $44^{\circ} 34^{\prime} 891^{\prime \prime}-44^{\circ} 35^{\prime} 461^{\prime \prime}$.

The Uhry Pits are situated within the NE-rim syncline of the Dorm-Beienrode salt diapir; the Walbeck Pits relate to subrosion bowls in the Upper Permian Zechstein, Upper Aller Valley Structure ([22], Figure 3(A)). The unconsolidated quartz sand deposits represent relics of an originally eroded transitional estuarian system developed through Maastrichtian in NE Germany.

\section{Geologic Setting}

As part of NW Europe, the Subhercynian situated in the Harz Mts' foreland, has been structurally formed by a transpressive orthogonal fault system (NNE-SSW, WNW-ESE) linked the interplay of N Atlantic Opening, the Fennoscandian Block and Alpine Mountain Building with it is (Figures 3(A)-(C)) built up by seven blocks that are separated by Zechstein evaporates, the latter's follow halocinetically the WNW/ESE-striking transpressive faults [22] [23] [24] [25]. The evaporates represent mobilization zones between the blocks resp. between the underlying Paleozoic Basement (subsalinar) and the Mesozoic/Cenozoic overburden (suprasalinar). The Maastrichtian quartz arenite deposits have been preserved in trap portions of the salt structures at Uhry ([26]-[31]; Figures 4(A)-(C)) and at Walbeck/Weferlingen ([32] [33] [34]; Figure 5).

Since the late Paleozoic the subsurface of the subhercynian dips stair-like SSW-ward ([22] [24]; Figure 3); raft tectonics may play an additional role [25].

\section{Paleogeography and Stratigraphy}

Since the Campanian/Maastrichtian B. both quartz arenite occurrences Uhry and Walbeck were deposited in a transitional estuarian environment where a system of braided rivers (low/median energy) prograded from SE toward NW toward the open sea ([26] [34] [35]; Figure 6).

The braid plains were fed by Variscan source areas and their Mesozoic overburden that formed a horse shoe-like ring across the hinterland comprising 

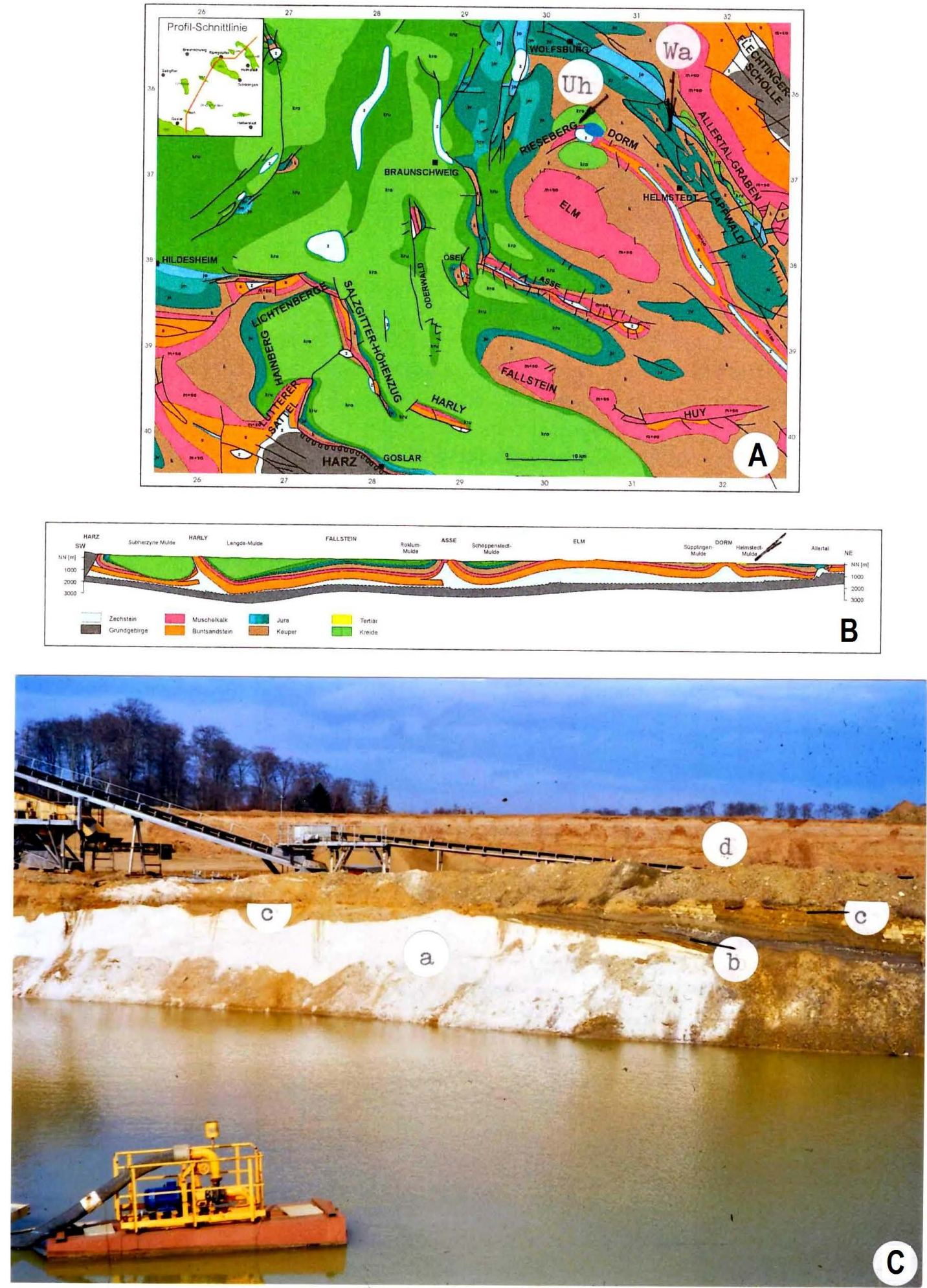

Figure 3. Geologic map of the Subhercynian without Cenozoic overburden. Uh Uhry, Wa Walbeck (A), Section across (A) see profile line (B) slightly modified from [22], and photograph of Evers pit, Uhry (C): a Upper Maastrichtian quartz arenite (white), b Lower Eocene pelite (black), c Eocene/Oligocene boundary represented by fluvial sand and mass flow [27] overlain with d: Pleistocene glaciofluvial and morain deposits. Latitude $57^{\circ} 97^{\prime} 500^{\prime \prime}$, Longitude $44^{\circ} 22^{\prime} 600^{\prime \prime} / 44^{\circ} 22^{\prime} 160^{\prime \prime}$ including Schlingmeier pit both located in the NE-rim syncline of the Dorm/Beienrode Salt Diapir. 


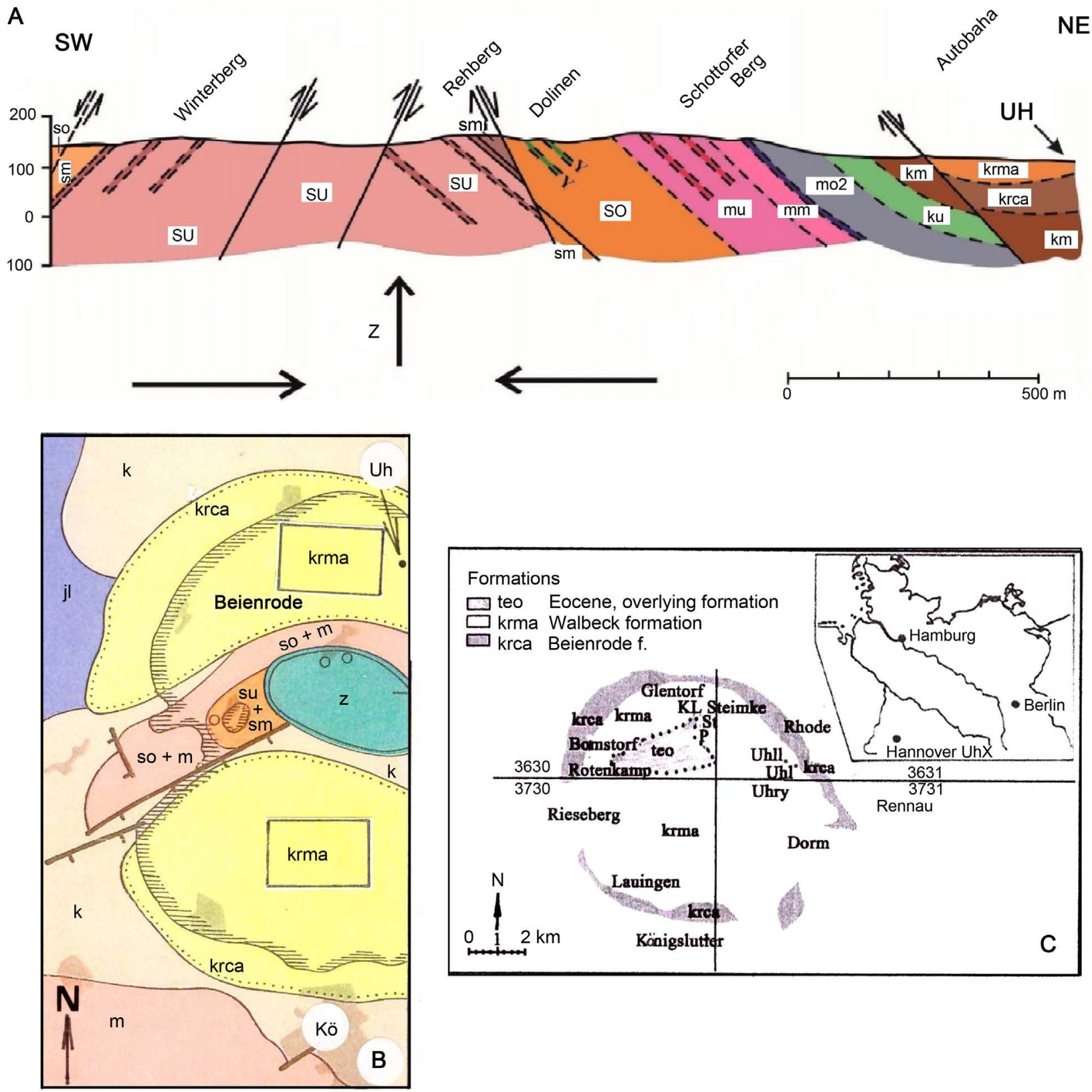

Figure 4. Geology of the Beienrode Basin and the Dorm Beienrode Salt Diapir. (A): Cross-section of the Dorm Anticline ESE of the Beienrode-Diapir representing post Maastrichtian diapirism (Z), su, sm, so: Lower Triassic, mu, mm, mo: Middle Triassic, ku, km, ko: Upper Triassic, krca: Campanian, krma Maastrichtian, Uh Uhry [24]-[31]. (B): Geologic map of the Beienrode Salt Diapir and its Rim Synclines without Cenozoic overburden: Campanian (krca) overlain with Maastrichtian (krma. Z Permian (Zechstein), s Lower Triassic, m Middle Triassic, k Upper Triassic, jl Lower Jurassic, Uh Uhry, Kö Königslutter [24]. (C): Beienrode Basin Filling: Lower Eocene relics (teo) overlying the Maastrichtian Walbeck F. (krma) and the Campanian Beienrode F. (krca). "Glass Sand" pit Schlingmeier Uh 1, Evers Uh 2 NE of Uhry village [26].

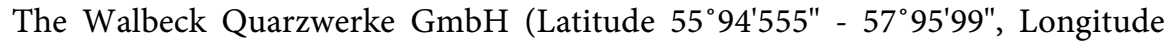
$\left.44^{\circ} 34^{\prime} 891^{\prime \prime}-44^{\circ} 35^{\prime} 461^{\prime \prime}\right)$ are located within Zechstein subrosion bowls of the Upper Aller Valley Structure [34].

Middle Germany [36], Elbe River Zone [37], Harz Mts. [36] and Flechtingen-Rosslau Ridge [36]. At all, the source areas have been built up by a 


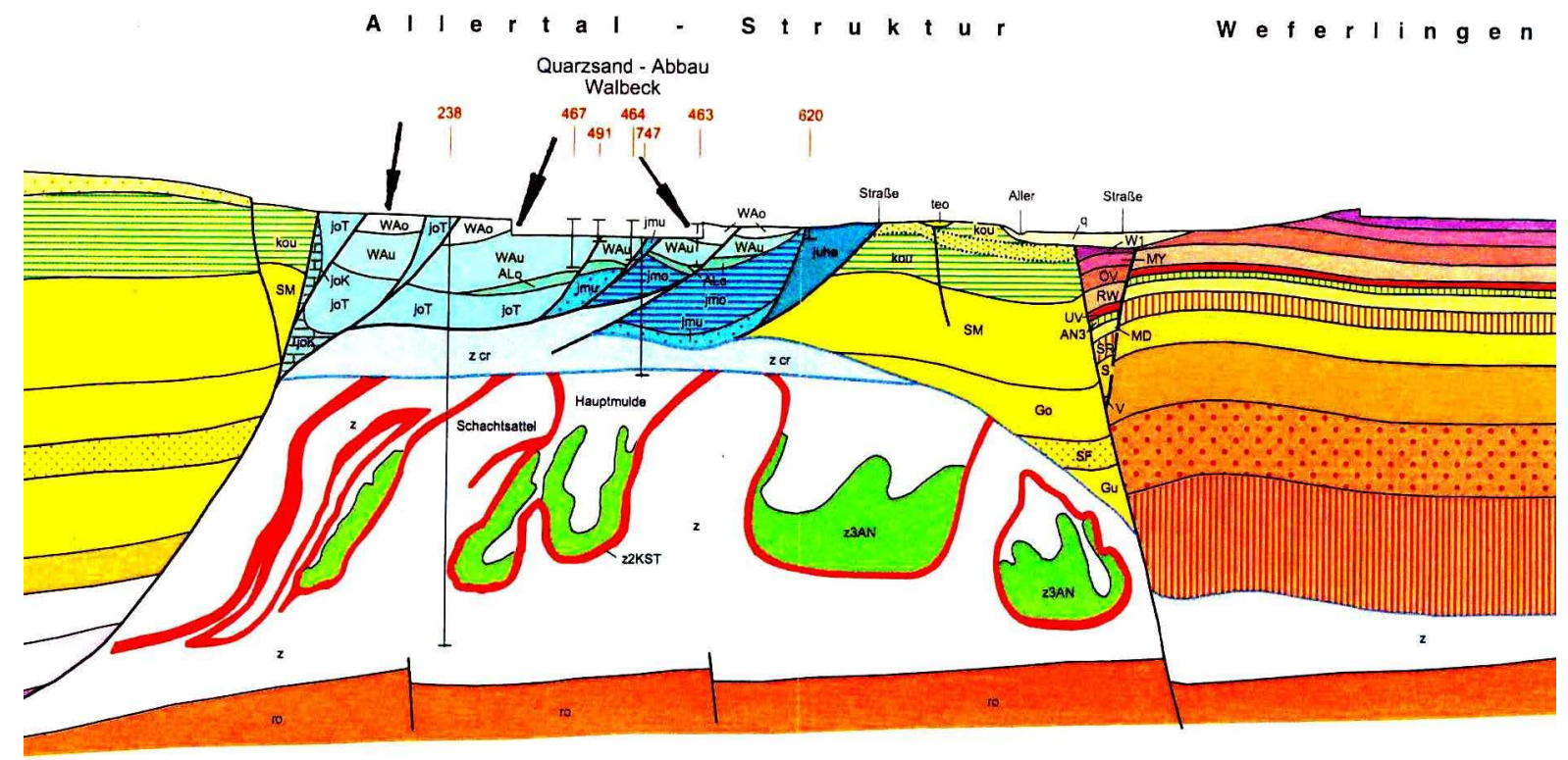

Figure 5. Geologic section across the Upper Aller Valley Structure at Walbeck; WAu and WAo = Lower and Upper Maastrichtian quartz arenite (Walbeck F,) overlying Zechstein Salt, its cap rock and Jurassic deposits in subrosion position. Right: Weferlingen Block (Lower Triassic), left: Lappwald Block (Lower and Middle Triassic), [34].

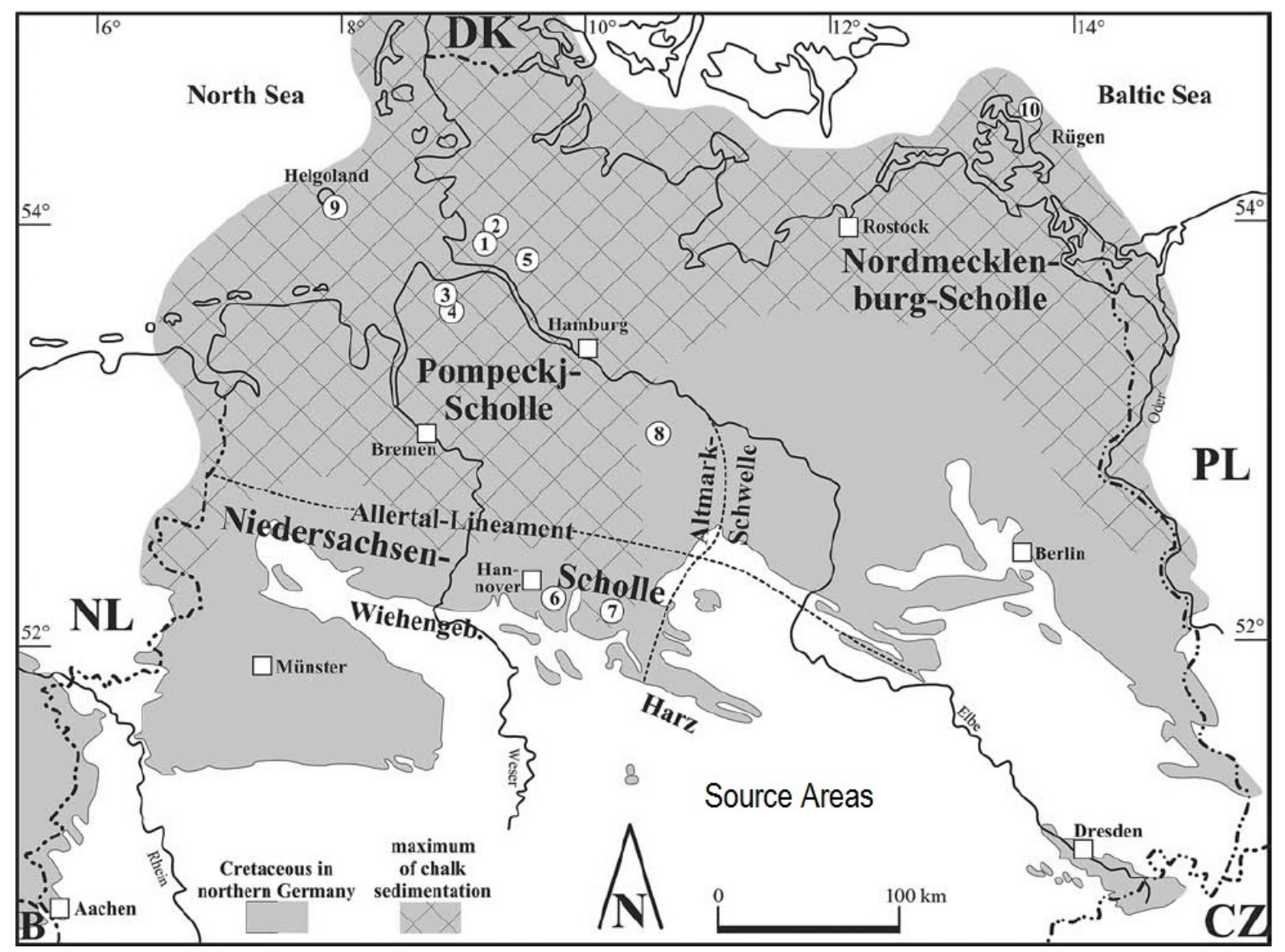

Figure 6. Maximum chalk deposition during Middle Campanian in North Germany [35, modified] and Maastrichtian fluvial/braid plain system running from SE $\rightarrow$ NW between Flechtlingen-Rosslau Ridge and Harz Mts. into the open sea. Alluvial fans prograded laterally from the latter source onto the major braid plains. 
broad spectrum of magmatic, metamorphic and clastic rocks, the latters of low maturity. So originally kaolinite-bearing arkosic/subarkosic clastics were deposited on and in front of the braid plains between fluvial, swamp, supratidal to intertidal, and shallow subtidal environments under warm climate along tens of SW-NE striking coastal kilometers [26] [34] [35].

Throughout Campanian and Maastrichtian, NW Germany was mainly covered with chert-bearing pelagic chalk deposits. The uppermost Maastrichtian (Reitbrook M.) that extends from Netherlands to the Baltic Sea, however, exposes calcarenite revealing top-eroded reworked intraformational chert conglomerates owning green-rimmed pebbles and fragments (tempestite deposits), [35]. The Maastrichtian/Danian hiatus comprises the KPgB (Figure 7(A) and Figure 7(B)), [35] [38] [39].

The age of the quartz arenite was unknown for a long time until an abundant macroflora and microflora one of the richest of Middle/Upper Cretaceous in NW Europe ( 450 species), was recovered at Walbeck [40] [41] that can be correlated with the chalk standard bore hole Offenseth 1 [35]. The latter does also comprise the KPgB [66.043 Ma:42].

The quartz arenite sections of both localities Uhry [26] [27] and Walbeck [34] expose interbedded poorly sorted sandy conglomerates whose pebbles, besides extra formational black lydite, volcanites, sandstones, are surprisingly composed of slightly silicified white radiolarite [suborders Acantharia, Spumellaria: 43]. Thus, undoubtedly their age is Maastrichtian and their primary skeletal

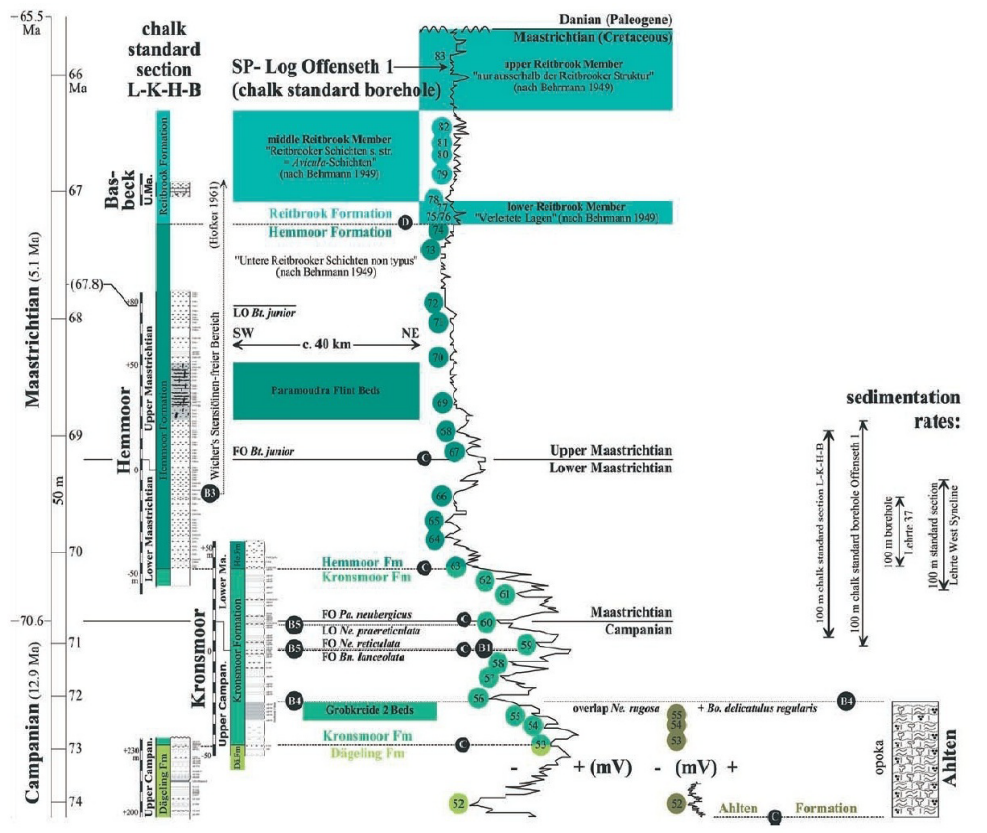

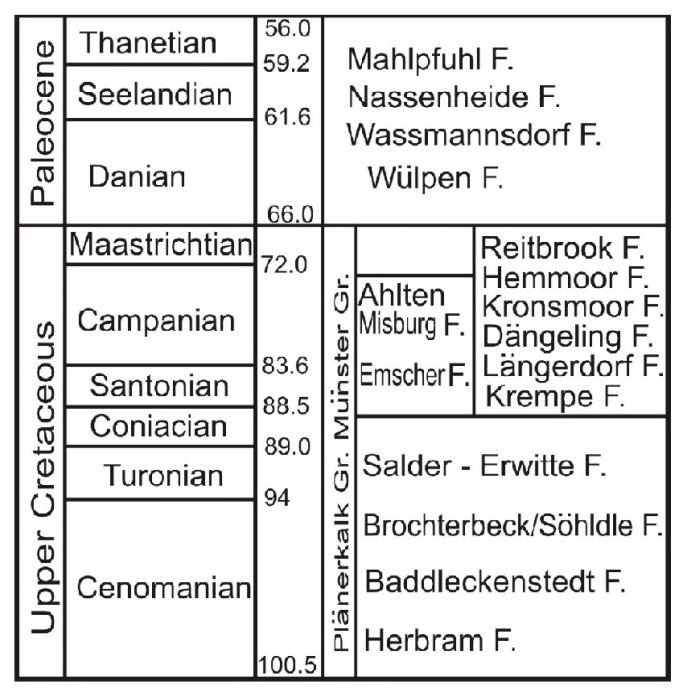

B

A

Figure 7. Stratigraphy and Correlation of the Campanian and Maastrichtian. (A). Multistratigraphic correlation of the chalk deposits with the standard bore hole Offenseth 1. See hiatus between the Upper Reitbrook M. and the Danian/Paleogene B. (KPgB) [35]. (B). Stratigraphic Table of the transitional section Maastrichtian (Walbeck F.)/Danian and eroded top portion in Germany $[38]$. 
substance was celestite and/or silica (Figure 8(A) and Figure 8(B)). Even more surprising is the verification of elementary silicon ( $\mathrm{Si}$ ) by X-ray diffraction besides $\beta$-quartz, unknown in nature (Figure $8(C)$ and Figure $8(D)$ ).

During Middle Campanian [conica/mucronate zone: 26] a continuous E-directed transgression covered NW Germany where NE $\rightarrow$ SW transported glauconite-bearing clastic were overlying the caprock of the Dorm/Beienrode Salt Pillow as flat submarine swell that developed during uppermost Maastrichtian and Paleocene to a salt diapir syn-genetically accompanied by rim synclines. The fauna yields low diversity and individual scarcity [26].

The Middle/Upper Campanian B. (75.1 Ma) introduced to the polyplocum regression combined with increasing faunal diversity and individual abundance that continued through Upper Campanian to be correlated with other outcrops in N Germany [26] [35]. Coarse calcarenite/-rudite layers interbedded in common glauconite sand indicate storm events (tempestite).

A hiatus in the off-shore chalk deposits (Reitbrook M.) defines the Campanian/Maastrichtian. (70.6 Ma: Oebisfeld transgression) relating to the
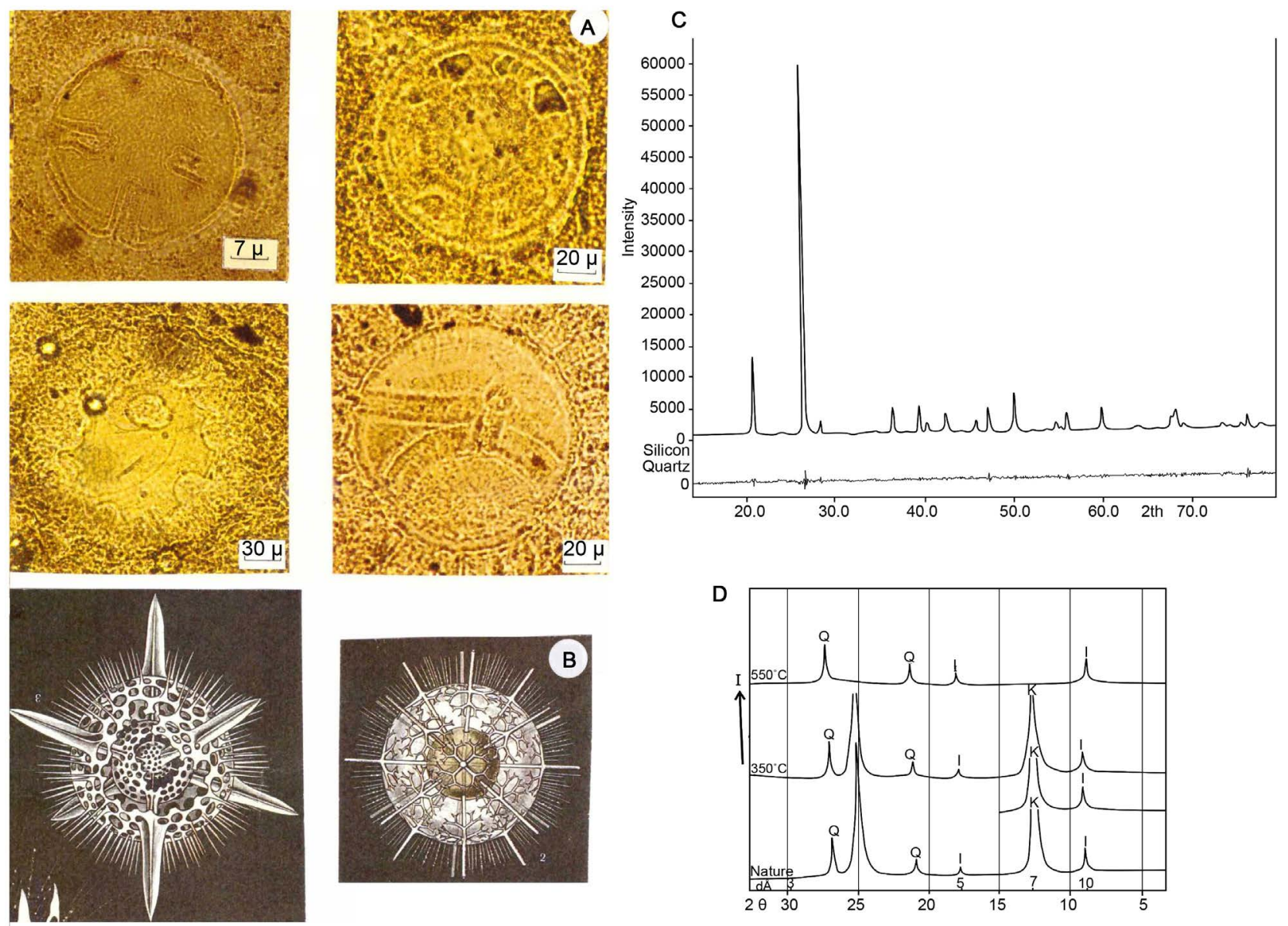

Figure 8. Maastrichtian radiolarian assemblage formed slightly consolidated radiolarite pebbles (primarily soft pebbles) in quartz arenite deposits (A): Suborders Acantharia and Spumellaria [27] [31] related to (B): [43]. X-ray diffraction analysis verifies as skeletal substance elementary silicon $\left(\mathrm{Si}^{0}\right)$ and $\beta$-quartz, white kaolinite dominates (besides illite) the clay fraction throughout the quartz arenite sequence $((C),(D))$. 
Global Stratotypye Section (GSSP: Figure 7(b)) while the hiatus at the base of quartz arenite section in the transitional environment shows a clastic transport change from $\mathrm{NE} \rightarrow \mathrm{SW}$ to $\mathrm{SE} \rightarrow \mathrm{NW}[26]$.

Ophiomorpha ichnofacies indicate intertidal and swamp environments (lignite) through the Lower Maastrichtian (Figure 9).

The Lower/Upper Maastrichtian B. $(69.3 \mathrm{Ma})$ coincides with the FO Belemnitella junior transgression documented by a chaotic mass flow that contains-besides extraformational pebbles-the white intraformational radiolarite "soft pebbles" (Figure 8, Figure 10(A) and Figure 10(B)) above mentioned. Both species Acantharia and/or Spumellaria skeletons are composed of quartz and elementary silicon. This event may be explained by a tsunami when transitional and pelagic sediments were reworked and jointly deposited in the developing rim syncline with increasing salinity.

Until the LO Belemnitella junior transgression $(67.8 \mathrm{Ma})$ chalk sedimentation continued intercalated with the Paramoudra Flint Sequence (pH-drop?), (FO first occurrence LO last occurrence).

A regressive phase marks in the following the onset of shallow water calcarenite deposition of the Reitbrook M. up to the KPgB-hiatus [35] [42].

It should be stressed that the multistratigraphy of the off-shore deposits is based on both macrofauna and microfauna, not always co-herent [35] and contrasting to the floral assemblages of the Uhry/Walbeck quartz arenite sequence.

The thickness of eroded top-portions of both Reitbrook M. and quartz arenite sequence is unknown. At Uhry the latter show a sharp discordance $\left(18^{\circ}-25^{\circ}\right)$ overlain with Lower Eocene pelite indicating salt diapirism throughout the

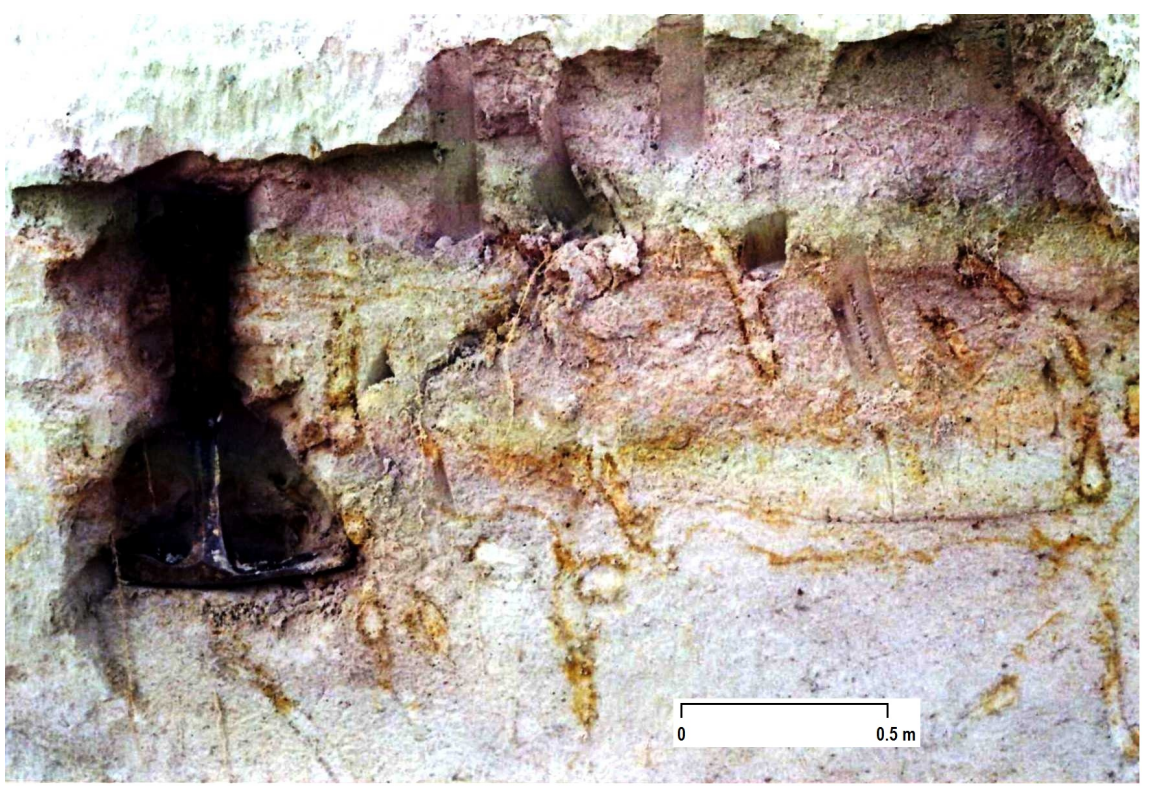

Figure 9. "Ghost structures" of Ophiomorpha ichnofacies penetrating quartz arenite indicating an intertidal/supratidal environment in the estuarian-transitional system of the Walbeck F., Evers pit, Uhry. 

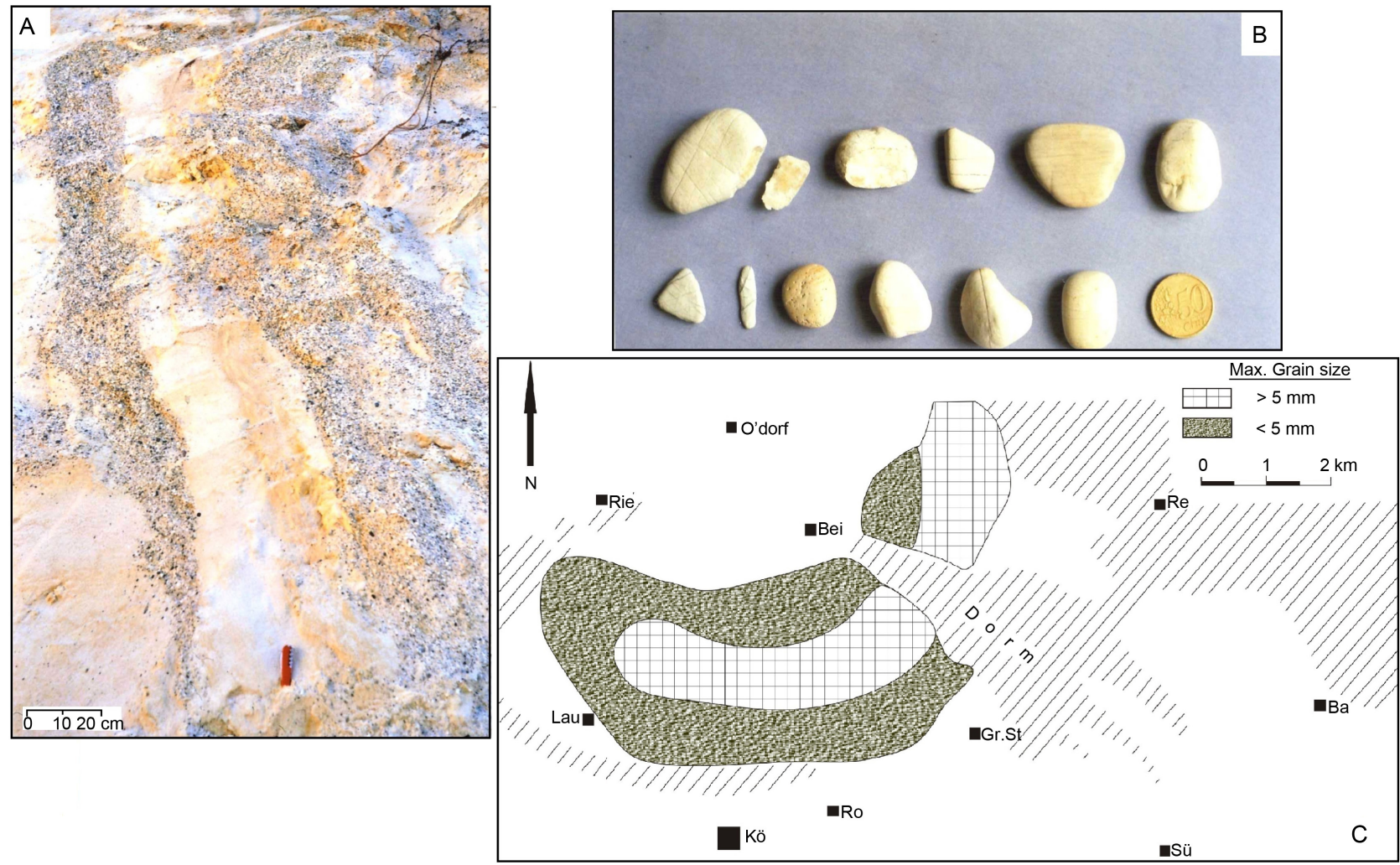

Figure 10. Sedimentology and distribution of radiolarite pebbles. (A): Conglomerate layers (white intraformational radiolarite, black extraformational lydite, dike quartz) intercalated in quartz arenite, steeply dipping SW-ward, SW rim syncline, Beienrode village. (B): Radiolarite pebbles from Evers pit, Uhry. (C): Distribution of radiolarite pebbles across the Beienrode Basin and both rim synclines showing coarse grain size along a horse show-like bar that may indicate a mouth of the estuarian system [31].

Paleocene (Figure 3(C)).

\section{Sedimentology, Mineral Composition and Diagenesis}

The Maastrichtian quartz arenite sequence (Walbeck F.) owns a thickness of 300 $400 \mathrm{~m}$ at Uhry site resp. $72-122 \mathrm{~m}$ at Walbeck/Weferlingen area (=type locality), (Figure 11(A) and Figure 11(B)).

This sequence is generally built up with unconsolidated white/grey fine- to coarse-grained, kaolinite-bearing, carbonate-free quartz sand intercalated with sandy gravel beds. Varying sorting relates to more or less bimodal grain size distribution also caused by in-situ kaolinite neoformation from feldspar replacement ([44], Table 3).

Architectural elements comprise $\mathrm{CH}$ (channel), GB (gravel bar and bed forms), SB (sandy bed form), DA (downstream accretion), LA (lateral accretion), LS (laminated send sheet), F... (Fines) and according lithofacies types like Gm, $\mathrm{Gt}$, st, sh, sr, sf, F characterizing the distal transitional sedimentary environment [45].

The white intraformational radiolarite pebbles of the mass flow deposited at the Lower/Upper Maastrichtian B, are manifold distributed through the section and may reflect several tsunami events and/or reworking processes. 
Table 3. Granulometric data and mineral content of quartz arenite deposits from the Uhry and Walbeck pits [31] [34].

\begin{tabular}{|c|c|c|}
\hline & UHRY & WALBECK \\
\hline & \multicolumn{2}{|c|}{ Granulometry } \\
\hline Median (Md, m) & $0.13-1.68$ & \\
\hline Sorting $\sigma \mathrm{I}$ & $0.11-2.05$ & \\
\hline Skewness (SKI) & $-0.38-0.59$ & \\
\hline Light minerals & \multicolumn{2}{|c|}{ Grain Wt-\% } \\
\hline Quartz & $94-100$ & $99.6 \mathrm{SiO}_{2}(\mathrm{Qz}, \mathrm{Kaol})$. \\
\hline Feldspar & $0-6$ & $0.05 \mathrm{Fe}_{2} \mathrm{O}_{3}$ (Limonite) \\
\hline Mica & $0-1$ & $0.17 \mathrm{Al}_{2} \mathrm{O}_{3}$ (Kaol.) \\
\hline Glauconite & $0-4$ & \\
\hline Heavy Minerals & \multicolumn{2}{|c|}{ Grain WT-\% } \\
\hline Zircon & $7.0-77.1$ & $0.4-19.8$ \\
\hline Tourmaline & $3.3-42.4$ & $31.3-61.1$ \\
\hline Rutile & $2.7-37.5$ & $0.4-16.7$ \\
\hline Sphene & $0-1$ & \\
\hline Brookite & $0-4.5$ & \\
\hline Anatase & $0-4.9$ & \\
\hline Andalusite & $1.3-59.6$ & $24.4-40.3$ \\
\hline Epidote, Clinozoisite & $0-4.3$ & $0-0.6$ \\
\hline Hornblende & $0-5.0$ & - \\
\hline Garnet & $0-7.9$ & $0-0.2$ \\
\hline Staurolite & $0.3-4.3$ & $1.8-4.0$ \\
\hline Cyanite & $0.6-6.6$ & $1.1-5.9$ \\
\hline Topas & - & $1.7-2.9$ \\
\hline Apatite & $0-4.9$ & $0-0.1$ \\
\hline Clay Minerals & Kaolinite, (illite) & Kaolinite, (illite) \\
\hline
\end{tabular}

Mapping work recovered a characteristic distribution of the pebbles (up to 5 $\mathrm{cm}^{\circ}$ )—originally wave-and current-rounded soft pebbles!-across the Beienrode Basin and both rim synclines. A horse shoe-like bar underlines the transitional figuration in an estuarian to inter/subtidal environment ([31], Figure $10(\mathrm{C})$ and Figure 11).

Quartz (94\% - 100\%) is almost the unique light mineral within both rim synclines at Uhry (Table 3); feldspar, mica and glauconite are subordinately present outside of them. Accordingly, chemical analysis of Walbeck quartz arenite reveals $99.6 \% \mathrm{SiO}_{2}, 0.05 \% \mathrm{Fe}_{2} \mathrm{O}_{3}$ (limonite) and $0.17 \% \mathrm{Al}_{2} \mathrm{O}_{3}$ [34]. Quartz appears as detrital grain, authigenic neoformation and as syntaxial overgrowth on detrital grains. 


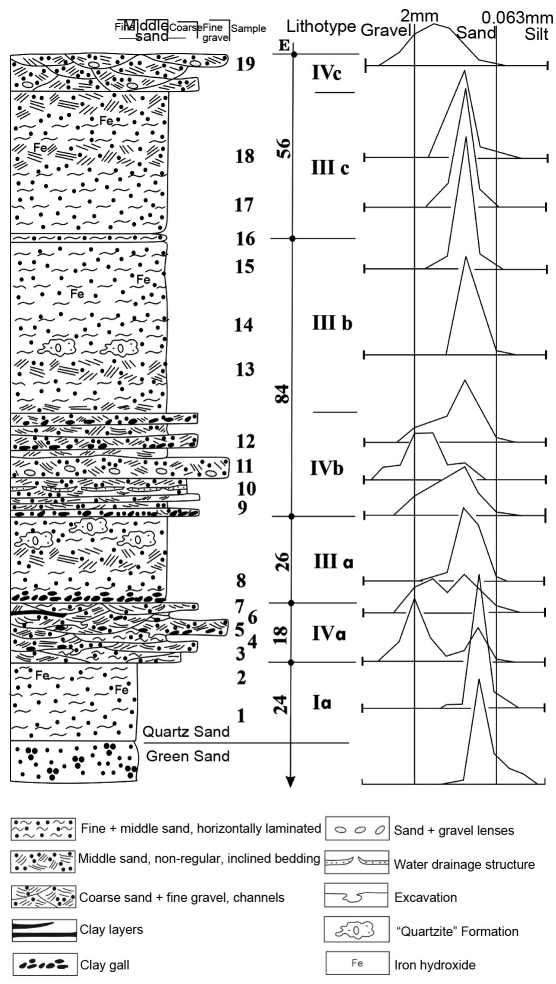

A

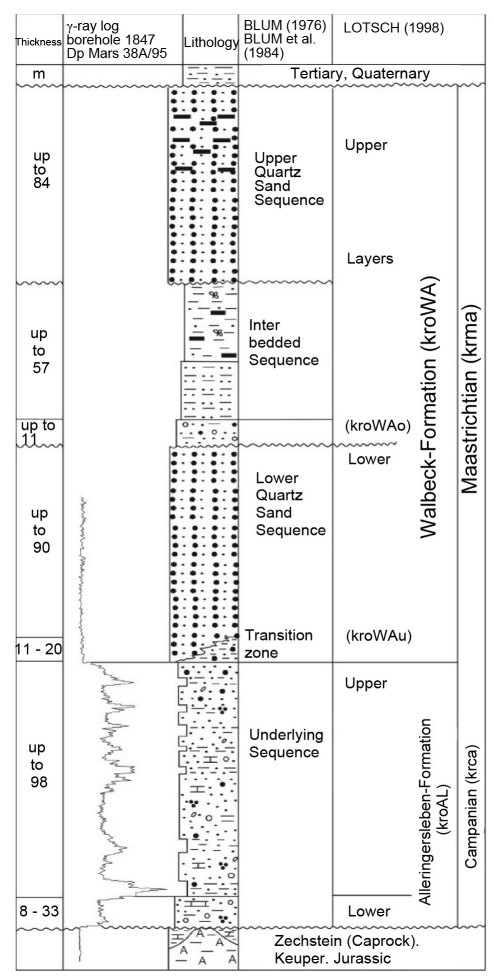

B

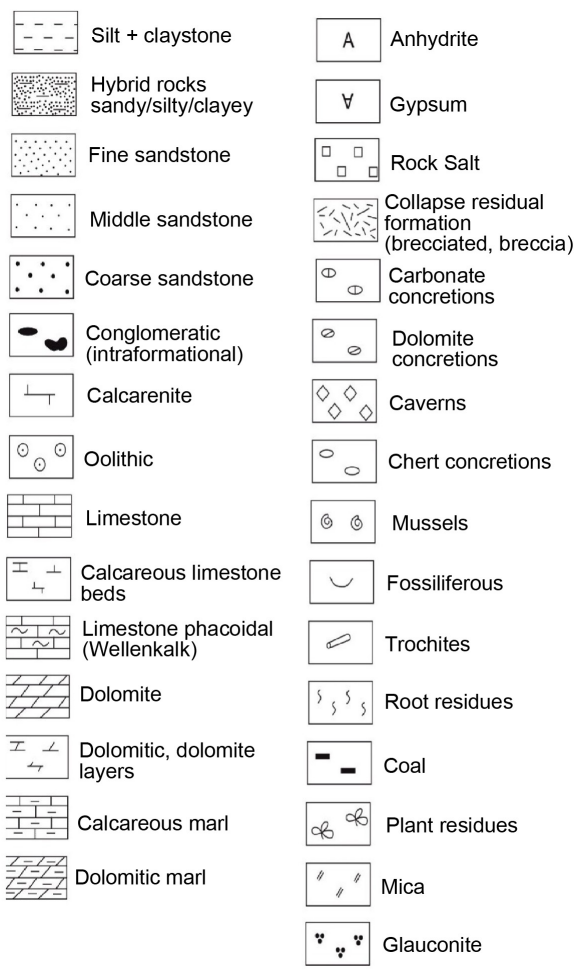

C

Figure 11. Lithostratigraphy of the Maastrichtian quartz arenite sequence at Uhry (A), [26] and Walbeck (B = type locality) [34].

Ultrastable heavy minerals (zircon, tourmaline, rutile, brookite, anatase) offer a broad quantitative spectrum inside and outside the rim synclines while the rare minerals epidote/clinozoisite, staurolite, cyanite, topas, apatite and especially the unstables like hornblende and garnet are found only outside [31], thus indicating a special pore water chemistry (Table 3).

With regard to the "heavies", as contact metamorphic mineral to be derived from the nearer located source areas of both Harz Mts. and Flechtingen/Rosslau Block, the content of andalusite represents its high resistance under low pH-conditions.

Kaolinite together with less illite, was certainly transported to the depositional environment; however, a high amount is the product of feldspar dissolution.

Concerning diagenetic processes, the original sediment was represented by more or less well sorted fine- to median-grained subarkosic/arkosic arenite during deposition owning a porosity of $\sim 30 \%$.

During the Belemnitella junior transgression a $\mathrm{pH}$-rise caused silica availability for the later syntaxial overgrowth of quartz grains and geod formation (Figure 12) after a pH-drop.

In connection with increasing brine influx from the adjacent salt structure, the KPg-event itself brought acid rain and caused the extreme $\mathrm{pH} /$ Eh-conditions cited in the Introduction, to generate the paragenesis $\beta$-quartz, silicon ( $\mathrm{Si})$ and kaolinite, possibly through Paleocene (compare Atlantis II-Deep, Red Sea). 


\section{End-Cretaceous Events: Plate Tectonics, Major Impacting, Plume Volcanism, Oceanic Arc Formation, a Synopsis (Figure 13)}

After Price [21], the abrupt change of both direction and speed of plate motion would indicate a major impact though, hitherto, relating craters haven't been verified except Chicxulub site (Figures 14(A)-(D)). Having used a former time scale [46] he put the $\mathrm{KPgB}$ on $66.025 \mathrm{Ma}$ that differs little from the most modern one (66.043 Ma) identical with the Chicxulub event [19].

Providing a great help for our data analysis, the latter authors applied a new stable and clumped isotope analysis, temperature record using bivalves and ammonites sp. of a hiatus-free KPgB-section on Seymour Island, Antarctica in regard to species extinction through the time-span Deccan Volcanism onset [47: 66.228 Ma resp. 42: 66.38 Ma] until the KPgB-event ( 150.000 - $300.000 \mathrm{yr}$ ). The first pulse presents a temperature rise of $7.8^{\circ} \mathrm{C} \pm 3.3^{\circ} \mathrm{C}$, the second one of $\sim 1.1^{\circ} \mathrm{C}$ $\pm 2.7^{\circ} \mathrm{C}$ both as extinction events [19].

During the extinction period the Deccan Trap Plume provided $\sim 150.10^{3} \mathrm{~km}^{3}$ [48] followed by $\sim 461 \times 10^{3}$ resp. $500 \times 10^{3} \mathrm{~km}^{3}$ after the KPgB until the end of Deccan volcanism [47: $65.05 \mathrm{Ma}$ ], so covering a time-span of $\sim 700.000$ yrs, both onset and end slightly delayed to those of chron $29 \mathrm{R}$ [19].

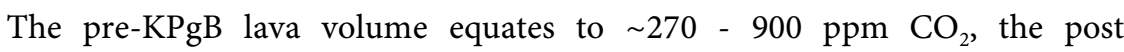
$\mathrm{KPgB}$-one to 830 - $900 \mathrm{ppm} \mathrm{CO}_{2}$ emitted to the atmosphere [19]. For comparison, the Maastrichtian $\mathrm{CO}_{2}$-level was calculated with 360 - 380 ppm.

Figure 13 exposes the relevant correlations through the Upper Campanian and Maastrichtian of the study area with the end-Cretaceous events:

- An Upper Campanian regressive phase meets the Caribbean/Antilles plume event $(73.1 \mathrm{Ma})$ when carbonate content decreased in off-shore chalk sediments while chert disappears in the overlying coarse-grained calcarenite possibly coinciding with a discordance $\left(18^{\circ} \mathrm{C}-23^{\circ} \mathrm{C}\right)$ in the estuarian transitional environment.

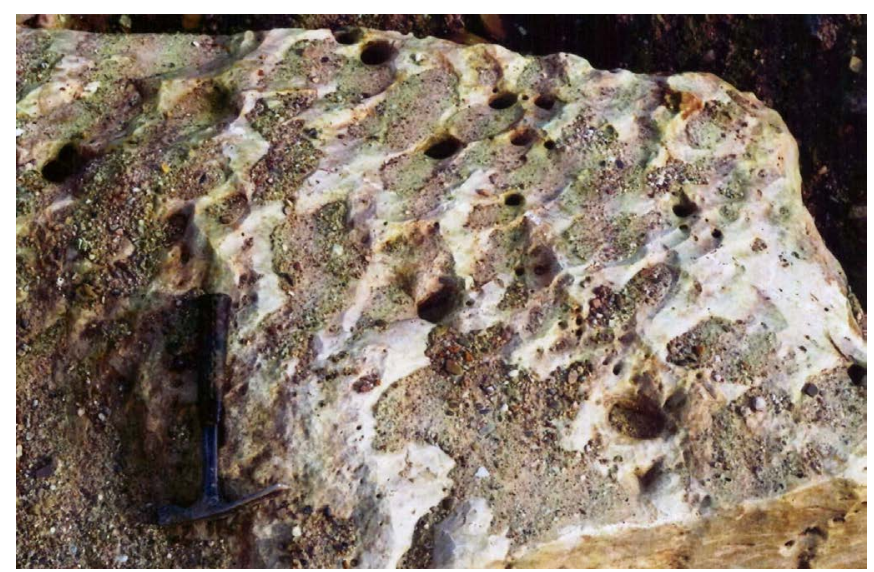

Figure 12. Concretionary quartzite block of early diagenetic origin with chemically unaffected bottom, however highly corroded top caused by a younger acid rain event. Evers pit, Uhry. 


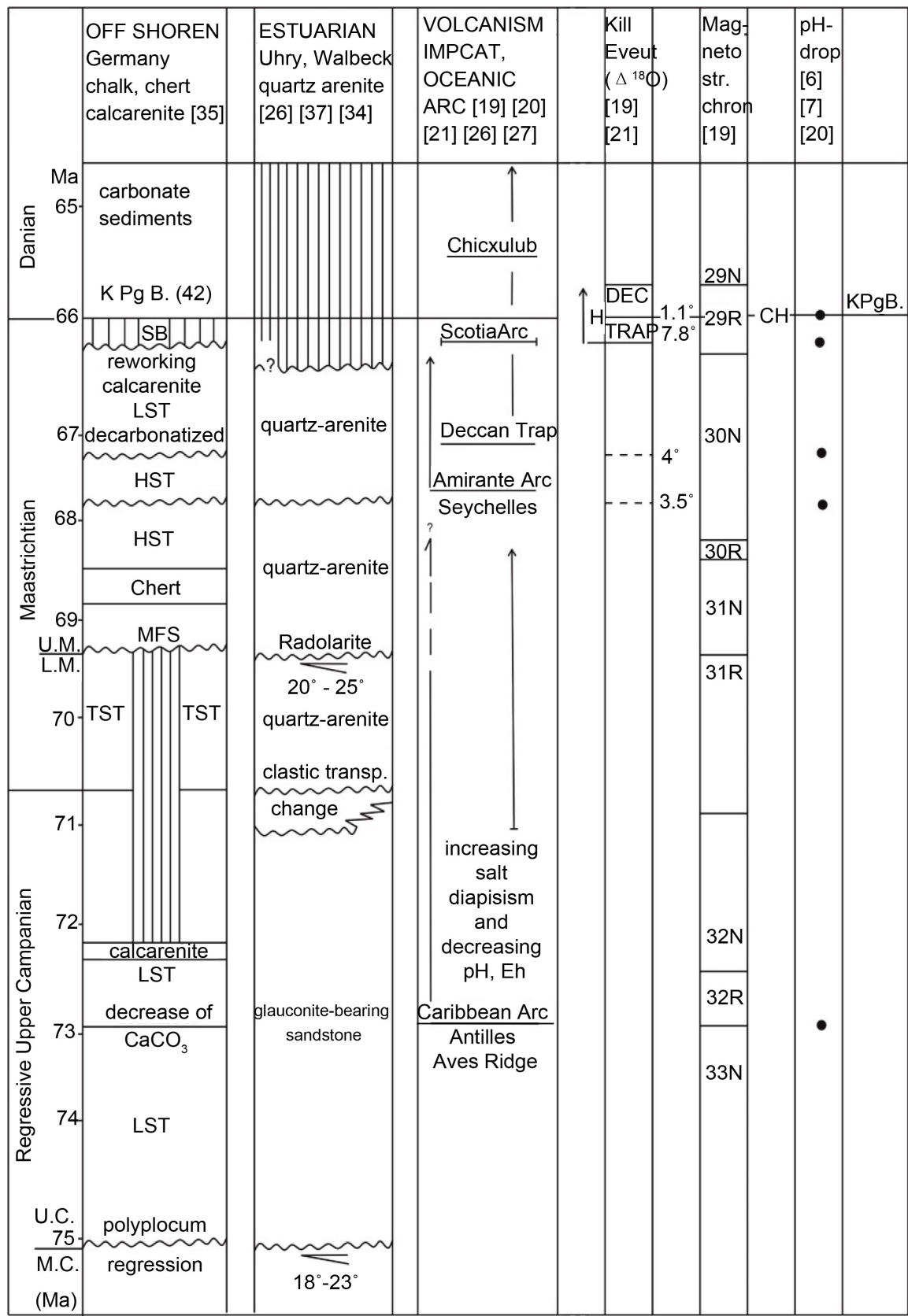

Figure 13. Synopsis of the Upper Campanian and the Maastrichtian chalk and quartz arenite deposition in North Germany/Subhercynian relating to plume volcanism (Deccan Trap, volcanic arc origin) and the Chicxulub impact verified by kill events, magnetostratigraphy and $\mathrm{pH}$-drop.

- The Campanian/Maastrichtian B. (70.8 Ma) coincides with a clastic transport change from NE $\rightarrow$ SW towards SE $\rightarrow$ NW (glauconitic calcarenite $\rightarrow$ quartz arenite).

- A transgressive phase occurred at the Lower/Upper Maastrichtian B. (FO Belemnitella junior, $69.3 \mathrm{Ma})$, accompanied by a discordance $\left(10^{\circ} \mathrm{C}-25^{\circ} \mathrm{C}\right)$ nd a basal mass flow mainly composed of intraformational off-shore radiolarite soft pebbles, thus coinciding with the Chron $31 \mathrm{R} / 31 \mathrm{~N} \mathrm{~B}$. 

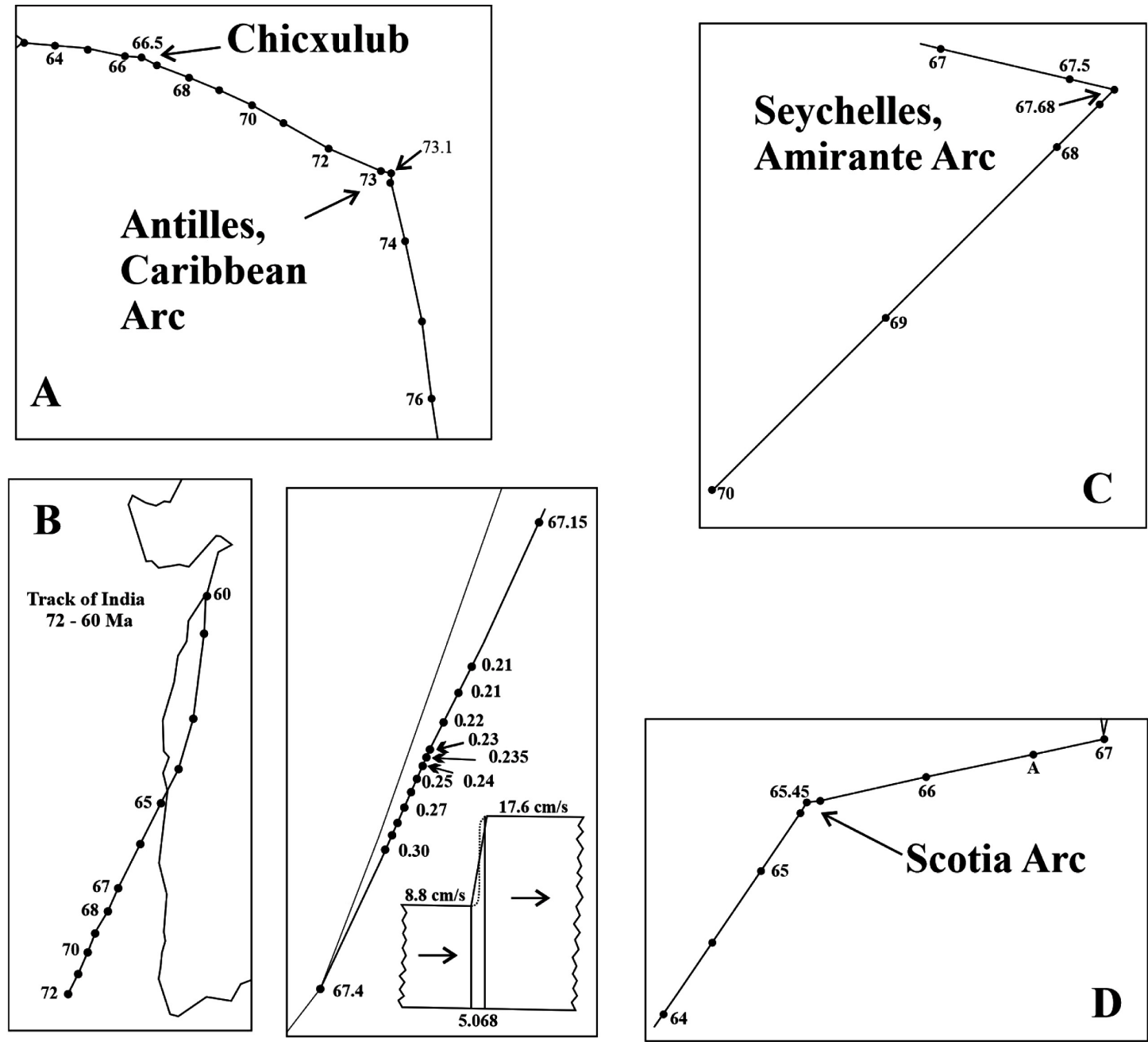

Figure 14. Tracks of end-Cretaceous plate motions. (A): track of easternmost Cape of Puerto Rico through the time-span 76 - 64 Ma; 73.1 Ma: Antilles, Caribbean Arc, 66.5 Ma: Chicxulub impact, Yucatan. (B): Track of India (Bombay), 72 - 60 Ma. Plate motion change $67 \mathrm{Ma}: 8.8 \mathrm{~cm} / \mathrm{s} \rightarrow 17.6 \mathrm{~cm} / \mathrm{s}$. (C): track of Reunion plume activity concerning Seychilles/Amrante Arc (70 - 67 Ma). Track change: 67, 68 Ma. (D) Track of an area of the west coast of S America between 70 - $60 \mathrm{Ma}$. Scotia Arc track changes: 65, $45 \mathrm{Ma}$.

- A warming event (19: $\sim 5^{\circ} \mathrm{C}$ : $67.8 \mathrm{Ma}$ ) during Chron $30 \mathrm{~N}$ coincides with the Amirante/Seychelles plume volcanism (67.7 Ma), LO Belemntella junior B., and a lithologic change by interstratified calcarenite).

- Another warming event [19: $\sim 4^{\circ} \mathrm{C}: 67.35 \mathrm{Ma}$ ] marks a regressive phase that initiated calc-arenite deposition of the Reitbrook M.; however, without facies change in transitional environments.

- Scotia Arc origination (Figure 16(D)) coincides with the onset of Deccan volcanism $(66.25 \mathrm{Ma})$ that represents the most important kill event [19, $\left.\sim 7.8^{\circ} \mathrm{C} \pm 3.3^{\circ} \mathrm{C}\right]$ after the beginning of Chron $29 \mathrm{R}$.

- The KPgB. Chicxulub impact: 66.043 Ma itself as second kill mechanism provided only a subordinate warming event during chron $\mathrm{R} 29$ [19: $\sim 11^{\circ} \mathrm{C} \pm$ $\left.2.7^{\circ} \mathrm{C}\right]$.

- The end of Deccan volcanism [19: 65.6 Ma] appears slightly delayed to Chron 
29R/29N B. as does its onset to $30 \mathrm{~N} / 29 \mathrm{R}$ B.

Despite the KPgB.-hiatus in N Germany, the following efforts may be taken in regard to end-Cretaceous magmatic degassing and acid-generated effects on sediments of the study area:

- Trace element analysis of reworked green-rimmed chert clastics of the uppermost Reitbrook M. [35].

- Analysis of unpublished core material of the Oil Industry from the uppermost Cretaceous relating to boundary clay and micropaleontologic pulses [35].

- Investigation of karst crevasse fills in limestone ("Muschelkalk") and in caprocks ("Zechstein”-gypsum) underlying Danian deposits in connection with quartz arenite at type locality Walbeck (Pflanzengarten) [34].

- Analysis of multicolored carbonate-free clay in connection with quartz arenite occurrence at both localities Ribbesdorf and Klinze, sheet Weferlingen [34].

\section{Discussion and Conclusions}

The end-Cretaceous temperature pulse record concerning the fauna applied at Seymour Island, Antarctica, exposes the major kill effect $\left(\Delta \mathrm{T} \sim 7.3 \pm 3.5^{\circ} \mathrm{C}\right)$ relates definitely to Deccan Plume Volcanism versus the minor pulse $(\Delta \mathrm{T} \sim 1.1 \pm$ $2.7^{\circ} \mathrm{C}$ ) that is to be linked with the Chicxulub impact [19]. So the results verify the dominant role of magmatic degassing: Deccan volcanism killed nine of ten benthic bivalve sp. and one of six pelagic ammonite sp. while the Chicxulub bolide extinguished six of fourteen bivalve sp., however, all ammonite sp. Obviously, both kill mechanisms operated differently during the interplay of degassing, chemical composition of target area (land, sea) trace metal toxicity, acidification of sea water, oceanic currents via climate change across different environments.

The consequences of these data make evident that an important loss of biodiversity may occur merely by plume volcanism which would restrict Price's concept [21] and major impacts may trigger plate motion. So in case of mass extinction without both verified plume activity and meteorite crater, its cause remains open. That concerns the results of our former papers dealing with Phanerozoic quartz arenite formation on the Arabian Platform, Jordan, too [15] [16].

Since all Deccan volcanism, Seychelles/Amirante Arc, Scotia Arc, and Caribbean Arc/Lesser Antilles don't indicate any hint on a meteorite crater, and plume volcanism provides the dominant kill mechanism via climate change through the end-Cretaceous period comprising quartz arenite formation in our North German study area, too.

Relating to magnetostratigraphy, the Seymour Island data underline the driving role of Earth's "D-layer" $(17,48)$ by indicating shortly delayed onset and end of Deccan volcanism to it during reversal magnetization (Chron 29R, Figure 15). 


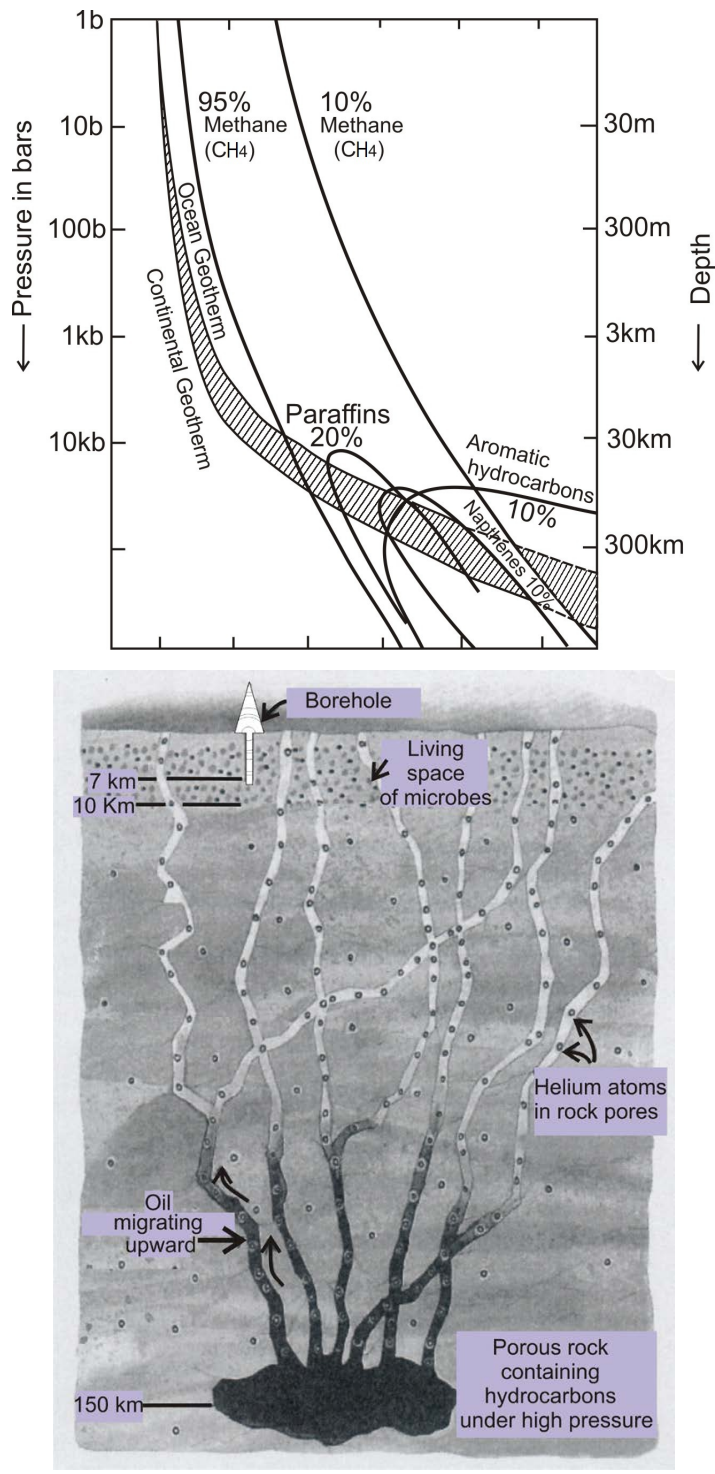

Figure 15. Hydrocarbon from the deeper Mantle [1, 49, 50, 51]. (A): Stability of hydrocarbons at temperatures/pressure conditions on Earth [49]. (B): Hydrocarbon and Helium ascent from "reservoir rocks" under high pressure in $\sim 150 \mathrm{~km}$ depth.

Modifying the Seymour Island data in a global project [20], $\partial^{11}$ boron isotope analysis of planktonic and benthic foraminifera skeletons relate the KPgB-mass extinction to the Chicxulub event within a wider realm of Deccan volcanism. Thereby, the driving kill mechanism focuses on impact-induced $\mathrm{pH}$-drop in ocean water to global ecologic collapse.

The authors analyzed surface water $\mathrm{pH}$-rebound sharply coincides with marine calcifier's extinction and associated imbalance of global carbon cycle ( $50 \%$ reduction of marine carbon isotope patterns at KPgB) [19] [20]. Primary productivity in surface water after KPgB took place not before a few tens of $10^{3} \mathrm{yr}$ while carbon export to deep-sea water was longer lasting [20].

Returning to volcanic degassing, in order to more realistically evaluate the gas 
volume of volcanic activity, the "heretic" concept of Th. Gold [1] shouldn't be neglected: in contrast to the majority of the global "hydrocarbon community", the author infers the original presence of hydrocarbons in the deeper Earth's Mantle since its consolidation $\left(\sim 4.5 \times 10^{9} \mathrm{Ma}\right)$ telling that exploited oil/ gas also may own an abiotic origin to be derived from the "deep hot biosphere" [1] [49] [50] [51]; (Figure 15(a) and Figure 15(b)).

Accordingly, methane does ascend in volcanic provinces (more or less slowly) from its primary depth to be oxidized moving through the upper crust, to $\mathrm{CO}_{2}$ and $\mathrm{H}_{2} \mathrm{O}$, finally accompanied by $\mathrm{CH}_{4}$ remains $(2 \%-5 \%)$. However, in case of fast magma ascent, with high volumes (plume v., increased MORB v., subduction v.) most of $\mathrm{CH}_{4}$ remains unoxidyzed (unmeasured) under reduced conditions (i.e. Krakatau, Santorin, Central America) [1].

Moreover, mud volcanoes in connection with earthquakes, may provide high $\mathrm{CH}_{4}$ volumes higher than those of economically exploited gas fields (Baku, Azerbaijan), in some cases enflamed up to $\sim 2000 \mathrm{~m}$ height above ground [1]. Similar happens on sea-floor (pockmarks $1-200 \mathrm{~m}^{\circ}$ ) encountered above North Sea gas fields or as "Pingos" in permafrost areas.

Thus, all in all, ascending primary fluid transform by decreasing pressure to a complex gas assemblage $\left(\mathrm{CH}_{4}, \mathrm{CO}_{2}, \mathrm{H}_{2}, \mathrm{~S}, \mathrm{H}_{2}, \mathrm{~N}_{2}, \mathrm{He}\right.$, Ra) whose total volume may be significantly higher as hitherto measured, consequently working as a primary mineral reduction in surface sediments.

Concerning silica-diagenesis, the unusual occurrence of elementary silicon ${ }^{\circ}$ in radiolarian skeletons hitherto unknown in nature, demands extremely reducing conditions $(\mathrm{Eh}<0)$ applied industrially by using $\mathrm{C}, \mathrm{Mg}$, AI, i.e.: $3 \mathrm{SiO}_{2}+4 \mathrm{Al}^{\circ} \rightarrow$ $3 \mathrm{Si}^{\circ}+2 \mathrm{AI}_{2} \mathrm{O}_{3}+169.4 \mathrm{kcal}[52]$.

Physical properties of silicon: dark grey, strongly glittering, hard brittle octahedral $\mathrm{D}=2.33 \mathrm{~g} / \mathrm{cm}^{3}$, melting point $1.423^{\circ} \mathrm{C}$, lattice structure like diamond, Si-Si distance $=2.34 \AA$.

$\mathrm{Si}^{\circ}$ is unsolvable in acids except $\mathrm{HNO}_{3}$. Regarding the depositional/diagenetic environment, the radiolarian pebble-bearing carbonate-free siliciclastics deposited in salt diapir trap position of the Beienrode Basin and Walbeck/Weferlingen subrosion bowls underwent stagnating saline pore water (mixture of fresh water, sea water, acid rain, brines) through a long lasting period (Upper Maastrichtian until lowermost Eocene!). Comparing this unusual diagenetic environment with that of the ATLANTIC II-DEEP, Red Sea, very low $\mathrm{pH}<4$ and negative Eh directed diagenesis [53].

Relating the data submitted to the end-Cretaceous sediments of N Germany ([35], Figure 13 and Figure 14) a first $\mathrm{pH}$-drop occurred at 72.9 Ma overlain with carbonate-reduced deposits correlating with the Caribbean Arc/Antilles plume volcanism. The next $\mathrm{pH}$-drop meets the LO Belemnitella junior B. (67.B $\mathrm{Ma}$ ) coinciding with the Amirante Arc/Seychelles volcanism and two other warming events $\left(\Delta \mathrm{T} \sim 3.5^{\circ} \mathrm{C}, \sim 4^{\circ} \mathrm{C}\right.$ : [19]) combined with a regressive phase exposing residual de-carbonized clayey deposits. Finally follow both, the prime warming Deccan volcanism $\left(\Delta \mathrm{T} \sim 7.8^{\circ} \mathrm{C}\right)$ and the "subordinate" Chicxulub im- 
pact pulse $\left(\Delta \mathrm{T} \sim 1.1^{\circ} \mathrm{C}\right)$.

Summarizing the driving causes in a global geodynamic feed-back system (compare [54]; Figure 16(A) and Figure 16(B)):
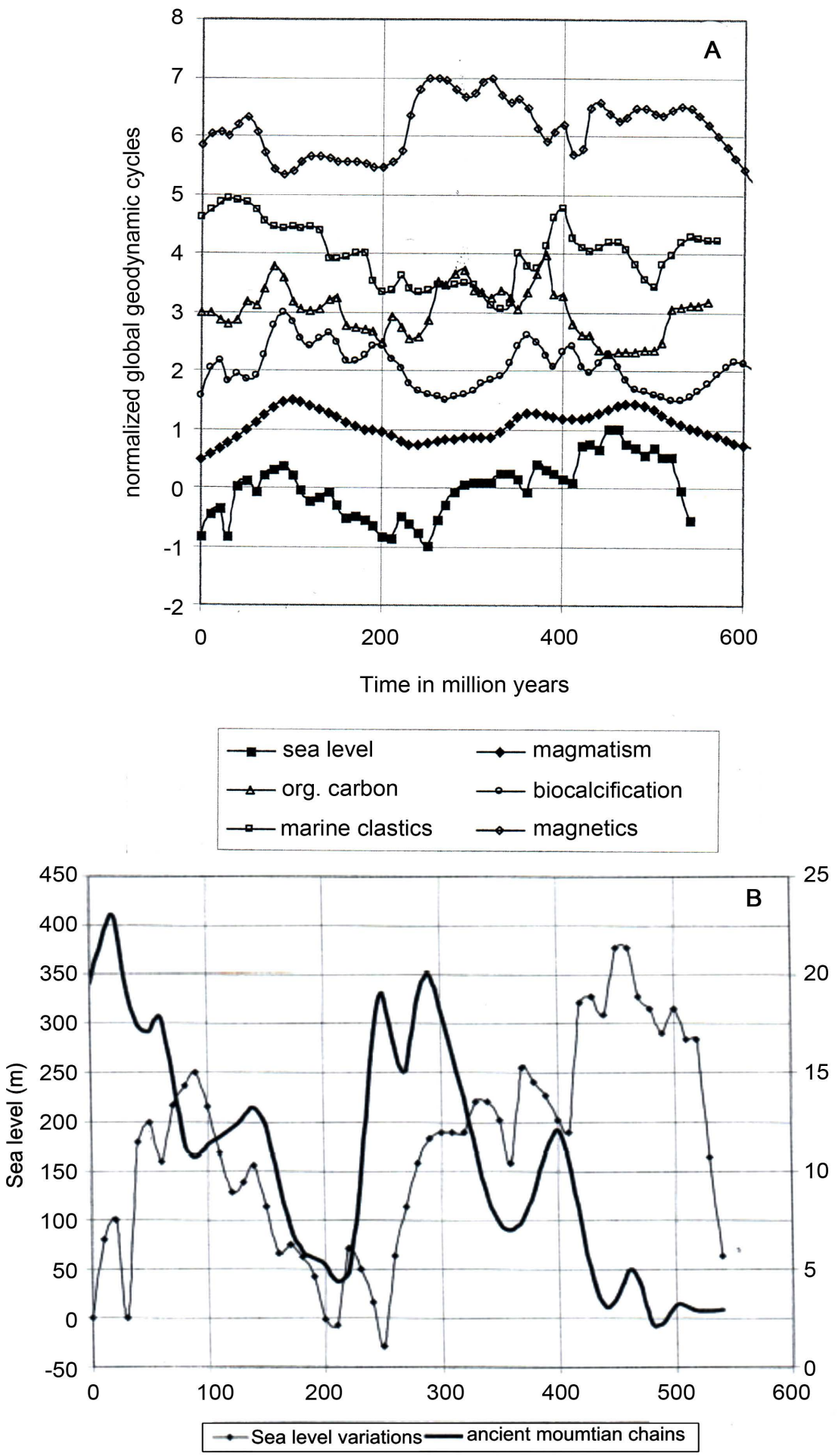

Figure 16. Driving causes in a global geodynamic feedback system [54]. (A): geodynamic cycles through the Phanerozoic. (B): Ancient mountain building and the level variation through the Phanerozoic. 


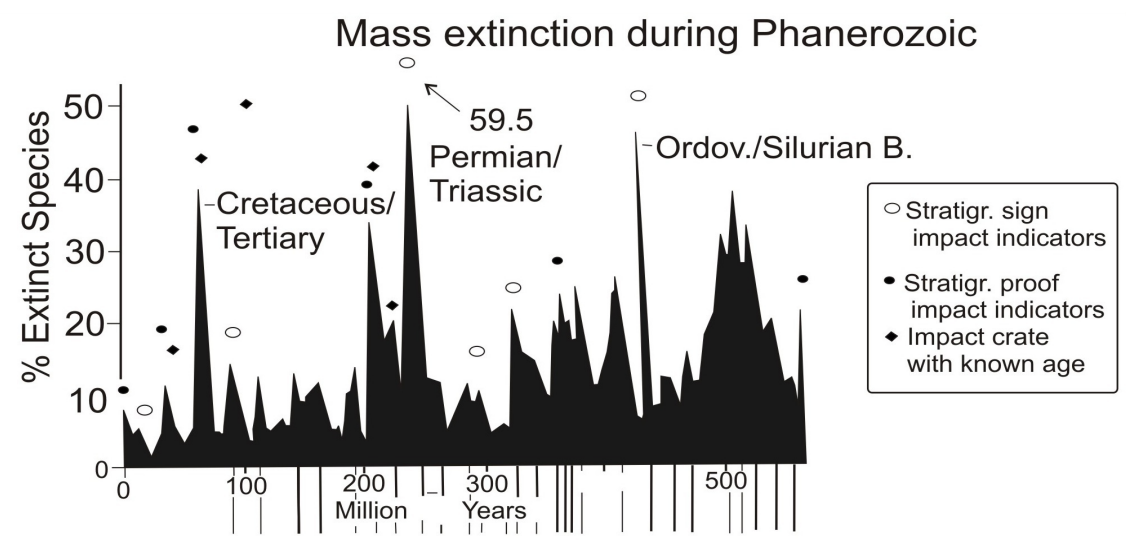

Figure 17. Mass extinction through the Phanerozoic under aspects of stratigraphy, impact events and plume volcanism [2] [55].

Table 4. Loss of Biodiversity and its causes through the Phanerozoic.

\begin{tabular}{|c|c|c|c|c|}
\hline $\begin{array}{c}\text { Stratigraphic Boundary } \\
\text { [35] [38] [39] [42] [46] [56] [57] }\end{array}$ & $\begin{array}{c}\text { Age (Ma) } \\
{[35][38][39][42]} \\
{[46][56][57]}\end{array}$ & $\begin{array}{c}\text { Plate track } \\
\text { change }(\mathrm{Ma}) \\
{[21]}\end{array}$ & $\begin{array}{c}\text { Event Mechanism } \\
\text { [2] [3] [8] [9] [20] [21] [55] [57] [58] }\end{array}$ & $\begin{array}{c}\text { Loss of (\% } \\
\text { Biodiversity) } \\
\text { [2] [55] [56] [57] } \\
\text { [58] }\end{array}$ \\
\hline Anthropocene & 1950-2010 A.D. & & $\begin{array}{l}\text { Progressive exploitation and combustion } \\
\text { of fossil resources }\end{array}$ & 18 \\
\hline Latest Holocene & $\begin{array}{l}\text { 1750-1950 A.D. } \\
\text { before }\end{array}$ & & Industrial Revolution & $\begin{array}{l}9 \\
3\end{array}$ \\
\hline Early Holocene & 9500 у B.P. & & Impact, Tektites & \\
\hline Pliocene (Zancleum/Piacencium) & $3.6-3.0$ & & $\begin{array}{l}\text { Increasing cooling in Europe } \\
\text { (Glaciation) }\end{array}$ & 6 \\
\hline Miocene & 15.0 & & Ries-Impact $\left(25 \mathrm{~km}^{\circ}\right)$ & $?$ \\
\hline Eocene/Oligocene & 33.75 & 34.6 & $\begin{array}{l}\text { Popigai Imp. }\left(100 \mathrm{~km}^{\circ}\right) \text { Chesapeake } \\
\text { impact, }\left(85 \mathrm{~km}^{\circ}\right) \text { et al. }\end{array}$ & 12 \\
\hline Cretaceous/Tertiary (= KPgB) & 66.043 & 66.25 & $\begin{array}{l}\text { Chicxulub Impact, Deccan Traps, } \\
\text { Oceanic Arcs' Volc. }\end{array}$ & 39 \\
\hline Campanian/Maastrichtian & 70.6 & 73.5 & Caribbean Arc Volc. & $?$ \\
\hline Albian/Cenomanian & 98.9 & 98 & \multirow{6}{*}{$\begin{array}{l}\text { Opening of the S Atlantic: } \\
\text { Super Plume Volcanism, } \\
\text { Hot Spot Tristan da Cunha, } \\
\text { Paraňa/Etendeka Flood Basalt }\end{array}$} & 13 \\
\hline Aptian/Albian & 112.2 & 113 & & 13 \\
\hline Barremian/Aptian & 121 & 119 & & \\
\hline Hauterivian/ Barremian & 127 & 125 & & 12 \\
\hline Valangian/Hauterivian & 132 & 131 & & 7 \\
\hline Berriasian/Valangian & 137 & 135.1 & & \\
\hline Tithonian/Berriasian & 142 & & $\begin{array}{l}\text { Mountain building, Greece; hiatus and } \\
\text { volcanism, Levante }\end{array}$ & 13 \\
\hline Norian/Upper Triassic & $211-207$ & 208 & Manicouagan impact $\left(100 \mathrm{~km}^{\circ}\right)$ & 34 \\
\hline Permian/Triassic & 251 & 250 & Siberian Flood B. & $70 / 90$ \\
\hline Frasne/Famenne & 374.5 & 368 & Siljan $\left(60 \mathrm{~km}^{ø}\right)$ & 24 \\
\hline Ordovician/Silurian & 443.7 & $\begin{array}{l}441 \\
439\end{array}$ & $\begin{array}{l}\text { Lockne }\left(13.5 \mathrm{~km}^{\circ}\right) \text {, } \\
\text { Sweden et al. }\end{array}$ & 46 \\
\hline
\end{tabular}


"D-layer" magmatism (core/mantle transition zone) defines magnetostratigraphy comprising plume volcanism (esp. oceanic flood basalt and increasing MORB-production and degassing $\rightarrow$ changing atmospheric chemistry $\rightarrow$ climate change, temperature rise, acid rain $\rightarrow \mathrm{pH}$-drop (sea water acidification, dissolution) $\rightarrow$ varying loss of biodiversity, influence on sequence-analytical patterns (i.e. cyclic fining upward) and sedimentary mineral assemblages $\rightarrow$ sea level rise (transgression), plate motion $\rightarrow$ subduction, mountain building, magmatic arc activity $\rightarrow$ increased erosion $\rightarrow$ clastic progradation (regression)...

Figure 17: [55] and Table 4 compile mass extinction with relevant kill mechanism through the Phanerozoic, showing a high loss variation of biodiversity caused by both volcanism and impacting; however, the predominant role of the first one versus "rare impact events" (comp. [21]).

Men-caused loss of biodiversity since the beginning of Industrial Revolution $(\sim 30 \%)$ falls on the upper level of Phanerozoic mass extinction and represents itself as a geological factor in Earth History [56] [57] [58].

\section{Acknowledgements}

We do appreciate G. Ramme's diploma-thesis, Braunschweig Technical University that initiated the entrance to our subject. We are grateful to Prof. Dr. D. Menzel, Institut für Physik der kondensierten Materie, Braunschweig Technical University for X-ray diffraction analysis of radiolarite pebbles. Moreover, many thanks to B. Paris and O. Schneider for digital support as well as to the quartz arenite pit owners for getting insight to their outcrops. Thanks go also to both Dr Ghaida'a Abdallat and Mrs Arwa Tarawneh for their efforts in preparing the figures.

\section{Conflicts of Interest}

The authors declare no conflicts of interest regarding the publication of this paper.

\section{References}

[1] Gold, Th. (2001) Biosphaere der heissen Tiefe. Ed. Steinherz, Wiesbaden. 2 Aufl., $256 \mathrm{p}$.

[2] Stöffler, D. (2002) Bedrohung aus dem Weltall-Asteroiden und Kometen. An den Fronten der Forschung. Kosmos-Erde-Leben. Verhandlungen der Gesellschaft Deutscher Naturforscher und Ärzte, 122, 81-97.

[3] Reimold, W.U. (2007) Revolutions in the Earth Sciences: Continental Drift, Impact and other Catastrophes. South African Journal of Geology, 110, 1-46.

https://doi.org/10.2113/gssajg.110.1.1

[4] Clifton, H.E., Ed. (1988) Sedimentologic Consequences of Convulsive Geologic Events. Geological Society of America, Special Papers, 229, 157 p. https://doi.org/10.1130/SPE229-p1

[5] Tollmann, A. and Tollmann, E. (1993) Und die Sintflut gab es doch. Vom Mythos zur historischen Wahrheit. München, $560 \mathrm{p}$. 
[6] Crutzen, P.J. (1987) Acid Rain at the K/T Boundary. Nature, 330, 108-109. https://doi.org/10.1038/330108a0

[7] Zahnle, K.J. (1990) Atmospheric Chemistry by Large Impacts. Global Catastrophes in Earth History, 247, 271-288. https://doi.org/10.1130/SPE247-p271

[8] Clube, V. and Napier, B. (1990) The Cosmic Winter. Blackwell, Oxford.

[9] Koch, H.P. (2000) The Diluvian Impact: The Great Flood Catastrophe 10,000 Years Ago as the Consequence of a Comet's Impact. Peter Lang Pub Incorporated, Europ. Verlag der Wissensch., Wien, New York, 27/4 p.

[10] Mc Lean, D.M. (1985) Mantle Degassing. Unification of the Trans-K/T Geobiological Record. In: Hecht, N.K., Wallace, B. and Prance, G.T., Eds., Evolutionary Biolo$g y$, Springer, Boston, 287-313. https://doi.org/10.1007/978-1-4615-6980-0_6

[11] Self, S., Widdowson, M., Thordarson, T. and Jay, A.E. (2006) Volatile Fluxes during Flood Basalt Eruptions and Potential Effects on the Global Environment: A Deccan Perspective. Earth and Planetary Science Letters, 248, 518-532.

https://doi.org/10.1016/j.epsl.2006.05.041

[12] Self, S., Schmidt, A. and Mather, T.A. (2014) Emplacement Characteristics, time Scales, and Volcanic Gas Release Rates of Continental Flood Basalt Eruptions on Earth. Geological Society of America, Special Papers, 505, 319-337.

https://doi.org/10.1130/2014.2505(16)

[13] Krauskopf, K.B. (1982) Introduction to Geochemistry. McGraw-Hill International Series, London, 617 p.

[14] Stöffler, D. (1971) Coesite and Stishovite in Shocked Crystalline Rocks. Journal of Geophysical Research, 76, 5474-5488. https://doi.org/10.1029/JB076i023p05474

[15] Schneider, W. and Salameh, E. (2012) Did Major Impacts Affect Sedimentologic/Sequence-Analytical Patterns of the Early Palaeozoic Sedimentary Systems of Jordan, Arabian Plate? Open Journal of Geology, 2, 241-252.

https://doi.org/10.4236/ojg.2012.24024

[16] Schneider, W. and Salameh, E. (2020) Phanerozoic Quartz Arenite Formation and Sequence-Analytical Patterns: Indirectly Relating to Major Impacting and Super Plume Volcanism, Jordan, Arabian Plate. Open Journal of Geology, 10, 13-52. https://doi.org/10.4236/ojg.2020.101002

[17] Larson, R.L. (1995) Die Superplume-Episode in der Mittleren Kreidezeit. Spektrum der Wissenschaft, 7, 48-52.

[18] White, R.W. and Saunders, A.D. (2005) Volcanism, Impact and Mass Extinction: Incredible or Credible Coincidences? Lithos, 79, 299-316. https://doi.org/10.1016/j.lithos.2004.09.016

[19] Peterson, S.V., Dutton, A. and Lohman, K.C. (2016) End-Cretaceous Extinction in Antarctica Linked to Both Deccan Volcanism and Meteoritic Impact via Climate Change. Nature Communications, 7, Article No. 12079. https://doi.org/10.1038/ncomms12079

[20] Henehan, M.J., Ridgwell, A., Thomas, E., Zhang, S., Alegret, L., Schmidt, J.R., Planavsky, N.J. and Hull, P.M. (2019) Rapid Ocean Acidification and Protracted Earth System Recovery Followed the End-Cretaceous Chicxulub Impact. PNAS, 116, 22500-22504. https://doi.org/10.1073/pnas.1905989116

[21] Price, N.J. (2001) Major Impacts and Plate Tectonics. Routledge, London, 354 p. https://doi.org/10.1201/9780203165454

[22] Baldschuhn, R. and Kockel, F. (1996) Geologische Schnitte 1:200000, Strukturübersicht und Lage der Geologischen Schnitte 1:500000. In Baldschuhn, R., Frisch, U. 
and Kockel, F., Eds., Geotektonischer Atlas von Nordwestdeutschland, Teil 17.7 and 17.8 Bundesanstalt for Geowissenschaften und Rohstoffe (BGR), Hannover.

[23] Lempp, Ch. and Lerche, I. (2006) Correlation of Stress Directions across the North German Basin: Suprasalt and Subsalt Differences. Zeitschrift der Deutschen Geologischen Gesellschaft, 157, 279-297. https://doi.org/10.1127/1860-1804/2006/0157-0279

[24] Kockel, F. (1991) Die Strukturen im Untergrund des Braunschweiger Landes. GeologischesJahrbuch, $A, 127,391-404$.

[25] Schneider, W. (2017) Post-Santone Flosstektonik im Subherzyn, Nördliches Harzvorland. Kurzfassung. Bericht an Bundesgesellschaft für Endlagerung (BGE), Salzgitter, 31 Abb., 21 p. (Unpublished)

[26] Niebuhr, B and Ernst, G. (1991) Faziesgeschichte und Entwicklungsdynamik von Campan, Maastricht und Eozän in Beienroder Becken Ost-Niedersachsen). Zeitschrift der Deutschen Geologischen Gesellschaft, 142, 351-283. https://doi.org/10.1127/zdgg/142/1991/251

[27] Schneider, W. and Salameh, E. (2018) How to Trace out Impact-Triggered Effects Globally Scattered around Formation Boundaries: Case Uhry, North Germany (Eocene/Oligocene Boundary). Open Journal of Geology, 8, 9-32. https://doi.org/10.4236/ojg.2018.81002

[28] Stänicke, J. (1979) Geologische Kartierung auf Bl. Süpplingen, (Nr. 3731). Dipl. Kart., TU Braunschweig, M. 1:10.000, 56 p.

[29] Probst, U. (1980) Kartierung auf Bl. Süpplingen (Nr. 3731), Dipl. Kart., TU Braunschweig, M 1:10.000, $62 \mathrm{p}$.

[30] Freiberg, H.-J. (1981) Kartierung auf Bl. Süpplingen (Nr. 3731), Dipl. Kart., TU Braunschweig, M 1:10.000, $62 \mathrm{p}$.

[31] Ramme, G. (1982) Sedimentologische Untersuchungen an tertiären Sanden (Meanwhile Corrected to Upper Maastrichtian) im Bereich des Dorm/Norddeutschland, Dipl.-Thesis, Braunschweig Technical University, $138 \mathrm{p}$ and an Additional Report about "Glass Sand" of the Same Age. (Unpublished)

[32] Best, G. (1996) Flosstektonik in Norddeutschland: Erste Ergebnisse reflextionsseimischer Untersuchungen an der Salzstruktur "Oberes Allertal”. Zeitschrift der Deutschen Geologischen Gesellschaft, 147, 455-464. https://doi.org/10.1127/zdgg/147/1997/455

[33] Best, G. and Zirngast (2002) Die strukturelle Entwicklung der exhumierten Salzstruktur "Oberes Allertal" Bundesanstalt f. Geowissensch. Und Rohstoffe (BGR), Hannover, 110 p.

[34] für Geologie, L. and Sachsen-Anhalt, B. (2007) Erläuterungen zur Geol. Karte von Sachsen-Anhalt, Bl. Helmstedt (3722), M 1:25000, 2 Aufl., 260 p.

[35] Niebuhr, B. (2006) Multistratigraphische Gliderung der norddeutschen Schreibkreide (Coniac bis Maastricht), Korrelation von Aufschlüssen und Bohrungen. Zeitschrift der Deutschen Geologischen Gesellschaft, 157, 245-262. https://doi.org/10.1127/1860-1804/2006/0157-0245

[36] Wagenbreth, O. and Steiner, W. (1990) Geologische Streifzüge. Landschaft und Erdgeschichte zwischen Kap Arkona und Fichtelgebirge. Deutscher Verlag f. Grundstoffindustrie, Leipzig, $204 \mathrm{p}$.

[37] Mattern, F. (1996) The Elbe Zone at Dresden: A Late Paleozoic Pull-Apart Intruded Shear Zone. Zeitschrift der Deutschen Geologischen Gesellschaft, 147, 57-80. https://doi.org/10.1127/zdgg/147/1996/57 
[38] German Stratigraphic Commission (Ed.) (2002) Stratigraphic Table of Germany, Explanation, $16 \mathrm{p}$.

[39] Ogg, J.G., Agterberg, F.P. and Gradstein, F.M. (2004) The Cretaceous Period. In: Gradstein, F.M., Ogg, J.G. and Smith, A.G., Eds., A Geologic Time Scale, Cambridge University Press, Cambridge, 344-383. https://doi.org/10.1017/CBO9780511536045.020

[40] Krutzsch, W. (1966) Die Spurenstratigraphische Gliederung der Oberkreide im nördlichen Mitteleuropa. Abhandlung Zentrales Geologisches Institut, 5, 111-137.

[41] Krutzsch, W. and Prokoph, A. (1992) Die Ablagerungen der oberkretazischen Walbeck F. im oberen Allertalgraben (Stratigraphie, Sedimentologie, Palynologie). Berichte der Naturhistorischen Gesellschaft, Hannover, 134, 117-133.

[42] Renne, P.R., Deino, A.L., Hilgen, F.J., et al. (2013) Time Scale of Critical Events around the Cretaceous-Paleogene Boundary. Science, 339, 684-687. https://doi.org/10.1126/science.1230492

[43] Rietschel, P. and Rohde, K. (2013) Die einzelligen Tiere. 4. Kapitel. In: Grzimek, B. Ed., Grzimek Tierleben. Enzyklopädie des Tierrech, Kinder Verlag, Zürich, 89-137.

[44] Folk, R.L. and Ward, W.C. (1957) Brazos River Bar [Texas]: A Study in the Significance of Grain Size Parameters. Journal of Sedimentary Research, 27, 3-26. https://doi.org/10.1306/74D70646-2B21-11D7-8648000102C1865D

[45] Miall, D. (1996) The Geology of Fluvial Deposits. Springer-Verlag, Berlin, Heidelberg, New York, 582. Hugendubel Verlag, Kreuzlingen/München, 317.

[46] Haq, B.U., Hardenbol, J. and Van Eysinga (1987) Geological Time Table. Elsevier, Amsterdam, Wall Chart.

[47] Schoene, B., Samperton, K.M., Eddy, M.P., et al. (2015) U-Pb Geochronology of the Deccan Traps and Relation to the End-Cretaceous Mass Extinction. Science, 347, 182-184. https://doi.org/10.1126/science.aaa0118

[48] Frisch, W. and Meschede, M. (2009) Plattentektonik. Kontinentverschiebung und Gebirgsbildung, 3. Auflage, Primus Verlag, Darmstadt, 196 p.

[49] Chekaliuk, E.B. (1976) The Thermal Stability of Hydrocarbon Systems in Geothermodynamic Conditions. In: Kropotkin, P.N., Ed., Degasatsia Zemli I, Geotectinica, Moskau Nauka, 267-272.

[50] Gold, Th. and Soter, St. (1980) The Deep-Earth-Gas Hypothesis. Scientific American, 242, 154-161.

[51] Gold, T. (1985) The Origin of Natural Gas and Petroleum, and the Prognosis for Future Supplies. Annual Review of Energy, 10, 53-77. https://doi.org/10.1146/annurev.eg.10.110185.000413

[52] Hollemann, A.F. (Wiberg, E., Ed.) (1964) Lehrbuch der Anorganischen Chemie, 70. Auflage, Walter de Gruyter \& Co., Berlin, 766 p. https://doi.org/10.1515/9783112312889

[53] Scholl, M., Bäcker, H. and Baumann, A. (1974) The Red Sea Geothermal System-New Aspects on their Brines and Associated Sediments. Problems of Ore Deposition. 4th IAGOD Symposium, Varna, V. 1, 303-313.

[54] Brink, H.-J. (2006) Do the Global Geodynamic Cycles of the Phanerozoic Represent a Feed-Back System of the Earth and is the Moon Involved as an Acting External Force? Zeitschrift der Deutschen Gesellschaft für Geowissenschaften, 157, 17-40. https://doi.org/10.1127/1860-1804/2006/0157-0017

[55] Rampino, M.R. and Heggerty, B.M. (1994) Extraterrestrial Impacts and Mass Extinctions of Life. In: Gehrels, T., Ed., Hazards Due to Comets \& Asteroids, Univer- 
sity of Arizona Press, Tucson, 827-857.

[56] Kriener, M. (2017) Dir grosse Beschleunigung. In: Edition de Monde Diplomatique: Warmzeit, Klima, Mensch und Erde. Berlin. No. 20, 109 p. (Source: Steffen Will et al. (2015) The Anthropocene Review, Berlin.)

[57] Böhme, N., Braun, H. and Breier, F. (2019) Wie wir Menschen wurden. Heyne, München, 335 p.

[58] Glaubrecht, M. (2019) Das Ende der Evolution. Der Mensch und die Vernichtung der Arten. C Bertelsmann, München, 1071 p. 